Columbia Law School

Scholarship Archive

1997

\title{
Old Chief v. United States: Stipulating Away Prosecutorial Accountability?
}

Daniel Richman

Columbia Law School, drichm@law.columbia.edu

Follow this and additional works at: https://scholarship.law.columbia.edu/faculty_scholarship

Part of the Constitutional Law Commons, and the Criminal Law Commons

\section{Recommended Citation}

Daniel Richman, Old Chief v. United States: Stipulating Away Prosecutorial Accountability?, 83 VA. L. REV. 939 (1997).

Available at: https://scholarship.law.columbia.edu/faculty_scholarship/747

This Article is brought to you for free and open access by the Faculty Publications at Scholarship Archive. It has been accepted for inclusion in Faculty Scholarship by an authorized administrator of Scholarship Archive. For more information, please contact scholarshiparchive@law.columbia.edu. 


\title{
OLD CHIEF $v$. UNITED STATES: STIPULATING AWAY PROSECUTORIAL ACCOUNTABILITY?
}

\author{
Daniel C. Richman*
}

\section{INTRODUCTION}

\begin{abstract}
$\mathrm{E}$
ARLIER this year, in Old Chief $v$. United States, ${ }^{1}$ the Supreme Court finally resolved a circuit sphit on a nagging evidentiary issue: When a defendant charged with being a convicted felon in possession of a firearm ${ }^{2}$ offers to satisfy one of the statute's elements by stipulating to the existence of a prior felony conviction, may the government decline the stipulation and prove tlie existence and the nature of that prior felony? ${ }^{3}$
\end{abstract}

-Visiting Associate Professor, University of Virginia School of Law; Associate Professor, Fordham University School of Law. Thanks to Dan Capra, Anne Coughlin, Jill Fisch, Richard Friedman, Nick Johnson, Pam Karlan, Nathan and Louise Katz, Larry Kramer, Jerry Lynch, Mike Martin, Bill Stuntz, Ben Zipursky, and participants in the University of Virginia Legal Studies Workshop for helpful comments, and to Fordham Law School for a grant in support of this project.

1117 S. Ct. 644 (1997).

2 Section $922(\mathrm{~g})$ states:

It shall be unlawful for any person ... (1) who has been convicted in any court of, a crime punishable by imprisonment for a term exceeding one year ... to ship or transport in interstate or foreign commerce, or possess in or affecting commerce, any firearm or ammunition; or to receive any firearm or ammunition which has been shipped or transported in interstate or foreign commerce.

18 U.S.C. $\$ 922(\mathrm{~g})(1994)$. Violations of this provision are punishable by fine or by imprisonment for up to ten years. See 18 U.S.C. $\$ 924(a)(2)-(b)(1994)$; see also 18 U.S.C. $\S 3665$ (1994) (providing for confiscation of firearms possessed by felons).

${ }^{3}$ Before the Court's decision, a majority of circuits had already barred the government from proving the nature of a defendant's prior felony where he offered to stipulate to the existence of a prior felony, or had at least suggested that admission of such evidence would generally be considered an abuse of discretion. See United States v. Tavares, 21 F.3d 1, 5 (1st Cir. 1994) (en banc); United States v. Gilliam, 994 F.2d 97, 102-03 (2d Cir.), cert. denied, 510 U.S. 927 (1993); United States v. Rhodes, 32 F.3d 867, 870-71 (4th Cir. 1994), cert. denied, 115 S. Ct. 1130 (1995); United States v. Poore, 594 F.2d 39, 40-43 (4th Cir. 1979); United States v. Palmer, 37 F.3d 1080, 1084-85 (5th Cir. 1994), cert. denied, 115 S. Ct. 1804 (1995); United States v. Wacker, 72 F.3d 1453, 1472-73 (10th Cir. 1995); United States v. O'Shea, 724 F.2d 1514, 1516 
The question of evidence law resolved in Old Chief is not particularly earth-shattering. Indeed, while the Court divided five to four on the issue, neither Justice Souter's opinion for the Court nor Justice O'Connor's dissent ventured beyond a relatively narrow doctrinal analysis. ${ }^{4}$ Evidence as to the nature of a defendant's prior felony conviction is indeed relevant, the Court reasoned, but the risk of unfair prejudice it presents far outweighs the probative value, once the defendant's proffered concession is considered as an alternative. ${ }^{5}$ Therefore, where a $\S 922(\mathrm{~g})(1)$ defendant is willing to admit having a prior felony conviction, the governinent inay not prove what that conviction was for. ${ }^{6}$ Save for its categorical approach to what generally is a fact-sensitive inatter, the decision is of a piece with so many judicial applications of Federal Rule of Evidence $403^{7}$ (or its state analogues), which, for fear of jury misuse, bar coinpelling proof on issues not seriously in dispute.

(11th Cir. 1984); United States v. Jones, 67 F.3d 320, $322-24$ (D.C. Cir. 1995). Three circuits found the government not obliged to accept such a stipulation. See United States v. Hudson, 53 F.3d 744, 747 (6th Cir. 1995); United States v. Burkhart, 545 F.2d 14 (6th Cir. 1976); United States v. Flenoid, 718 F.2d 867, 868 (8th Cir. 1983); United States v. Breitkreutz, 8 F.3d 688, 690-92 (9th Cir. 1993). The Seventh Circuit told trial judges to resolve the issue case by case, see United States v. Lomeli, 76 F.3d 146, 150-51 (7th Cir. 1996), and the Third Circuit had found no need to resolve the issue, see United States v. Jacobs, 44 F.3d 1219, 1224 (3d Cir.), cert. denied, 115 S. Ct. 1835 (1995).

No court permitted the government to prove up the conduct underlying the prior felony conviction.

${ }^{4}$ For a discussion of Justice Souter's brief venture beyond this narrow context, see infra notes 35-39 and accompanying text.

${ }^{s}$ There remains some dispute about whether, when a defendant stipulates to a prior felony, the jury should be instructed to treat that element as proven. Compare United States v. Mason, 85 F.3d 471 (10th Cir. 1996) (no error for trial court to instruct jury that prior felony and commerce elements of statute have been satisfied where defendant stipulates to the facts establishing those elements) with United States v. Jones, 65 F.3d 520, 522 (6th Cir.) (such an instruction is erroneous because a trial judge may not "override or interfere with the jurors' independent judgment") (citation omitted), vacated, 73 F.3d 616 (6th Cir. 1995), conviction aff'd, 108 F.3d 668 (6th Cir. 1997) (finding no need to decide whether instruction was erroneous because defendant did not object, suffered no prejudice, and error not plain).

'See Old Chief, 117 S. Ct. at 647.

${ }^{7}$ Fed. R. Evid. 403 ("Although relevant, evidence may be excluded if its probative value is substantially outweighed by the danger of unfair prejudice, confusion of the issues, or misleading the jury, or by considerations of undue delay, waste of time, or needless presentation of cumulative evidence."). 
Within the frame of the simgle case, Old Chief is simply an effort to remove a factor that Congress found of little moment when it cast $\S 922(\mathrm{~g})(1)$ 's broad prohibition. Perhaps it is a futile effort, though. The rule announced does not prevent juries from considering the nature of a defendant's felony. It merely deprives them of accurate information about it. ${ }^{8}$ The juror who gives any thought to the nature of a defendant's underlying felony can only speculate-speculation that will hikely be guided by stereotypes of race, gender and class, and that will simply be driven underground by mstructions that she not consider the defendant's prior record. Whether defendants will have the option of correcting misimpressions in this regard is a question troublingly left open by the Court's decision.

The questions raised by Old Chief, however, go far beyond the confines of evidence doctrine, and go to the relationship between evidentiary rules, prosecutorial discretion, and prosecutorial accountability. If citizens have any voice in the fine-grained decisions that prosecutors make about resource allocations, they have it not because of appointive or electoral politics but because prosecutors make cliarging-and plea bargaiming-decisions in the sliadow of jury verdicts, or at least projected verdicts. Yet such decisions are also made in the shadow of exclusionary evidentiary rules that often deprive jurors of the very information that they, as citizens, would find most relevant to prosecutorial priorities. Old Chief effectively creates just such a rule, based, as most evidentiary rules are, on considerations of fairness in the individual case. Are those considerations outweighed by the rule's systemic costs? If the Court is successful in bleaching out the difference in $\S 922(\mathrm{~g})(1)$ trials between the convicted murderer and the defendant with a less troubling record, will that make prosecutors neutral between such cases when deciding whetlier to bring cliarges? If one assumes, as many have, that prosecutors simply seek to maximize convictions, the answer is "yes." Indeed, if this assumption is true and if jurors' readiness to convict is driven by speculation about a defendant's record, then Old Chief tlireatens a world im which even race-neutral

\footnotetext{
${ }^{8}$ See Stephen A. Saltzburg, A Special Aspect of Relevance: Countering Negative Inferences Associated with the Absence of Evidence, 66 Cal. L. Rev. 1011 (1978).
} 
prosecutors select cases based on the worst sort of stereotypes. Should the rule be applied symmetrically, preventing defendants froin correcting juror misinpressions, it will be even more pernicious. In a world where prosecutors primarily sought to maximize convictions, the systemic costs of this, and inany other, exclusionary rules of evidence would therefore be considerable.

But do prosecutors really work this way? And if they are not trying to maximize convictions (or sentence-years), what are they trying to do? This Essay does not come close to answering this critical, but surprisingly under-studied question. By inquiring into the interaction between evidentiary rules, jury verdicts, and prosecutorial choices, however, it seeks to offer a richer account than has hitherto been provided of the significance of evidentiary rules in a criminal justice system in which trials alınost never happen. ${ }^{9}$ It also challenges us to inove forward beyond simphistic assumptions about prosecutorial inotivation-assumptions that are not inerely unhelpful but deter us from understanding how our systein really works (or doesn't).

\section{THE RULE IN OLD CHIEF}

\section{A. The Defendant's Dilemma}

Notwithstanding the broad availability and legality of firearms in the Umited States, the felon-in-possession statute ${ }^{10}$ sweeps

${ }^{9}$ During fiscal year 1995 , of the 47,868 defendants who were either acquitted or convicted in federal district court (i.e., whose cases were not dismissed), 43,103 (90\%) were convicted upon pleas of either guilty or nolo contendere. Bureau of Justice Statistics Sourcebook of Criminal Justice Statistics-1995, at 478 tbl.5.29 (Kathleen Maguire \& Ann L. Pastore eds., 1996) [hereinafter Sourcebook]. In 300 representative counties, $92 \%$ of convictions were upon guilty pleas. Id. at 498 tbl.5.47.

${ }^{10} 18$ U.S.C. $\$ 922(\mathrm{~g})(1)$. A precursor to this provision was enacted in the Gun Control Act of 1968, Pub. L. No. 90-618, 82 Stat. 1213 (codified at 18 U.S.C. $\S 1202$ (a)). See Lewis v. United States, 445 U.S. 55, 60-61 (1980) ("The statutory language [of $\S 1202(1)$ ] is sweeping, and its plain meaning is that the fact of a felony conviction imposes a firearm disability until the conviction is vacated or the felon is relieved of his disability by some affirmative action ..."). The current version of $\S 922(\mathrm{~g})$ was a part of the Firearms Owners Protection Act of 1986, Pub. L. No. 99-308, 100 Stat. 449 (1986).

Under 18 U.S.C. $\$ 925$ (c) (1994), a predicate felon otherwise barred from possessing a weapon under $\S 922(\mathrm{~g})$ may apply to the Treasury Department for relief, and the Secretary or his designate may grant such relief "if it is established to his satisfaction that the circumstances regarding the conviction, and the applicant's 
broadly: Anyone previously convicted of a felony, whether state or federal, can be prosecuted in federal court merely for possessing a firearm, and imprisoned for up to ten years. The government needs to show only: (1) that the defendant previously was convicted of a crime punishable by a term of imprisonment exceeding one year;, $(2)$ that the defendant knowingly possessed, transported, shipped, or received the firearm; and (3) that the possession was in or affecting colnmerce. ${ }^{12}$ No showing that a

record and reputation, are such that the applicant will not be likely to act in a manner dangerous to public safety and that the granting of the relief would not be contrary to the public interest." In the 1993 Appropriations Act for the Treasury Department, however, Congress specifically barred any funding for the Bureau of Alcohol, Tobacco and Firearms "to investigate or act upon applications for relief" under this provision, Treasury, Postal Service, and General Government Appropriations Act, 1993, Pub. L. No. 102-393, 106 Stat. 1729 (1992), and such a limitation was imposed in the next two Appropriation Acts as well, Pub. L. 103-123, 107 Stat. 1226 (1993); Pub. L. 103-329, 108 Stat. 2382 (1994). The circuits have split on whether these provisions effectively repealed the relief provision. Compare United States v. McGill, 74 F.3d 64, 67 (5th Cir. 1996) (yes), and Moyer v. Secretary of the Treasury, 830 F. Supp. 51618 (W.D. Mo. 1993) (yes), with Rice v. ATF, 68 F.3d 702, 707 (3d Cir. 1995) (no).

"Under $\$ 921(\mathrm{a})(20)$ (1994), the term "crime punishable by imprisonment for a term exceeding one year" does not include:

(A) any Federal or State offenses pertaining to antitrust violations, unfair trade practices, restraints of trade, or other similar offenses relating to the regulation of business practices, or

(B) any State offense classified by the laws of the State as a misdemeanor and punishable by a term of imprisonment of two years or less.

What constitutes a conviction of such a crime shall be determined in accordance with the law of the jurisdiction in which the proceedings were held. Any conviction which has been expunged, or set aside or for which a person has been pardoned or has had civil rights restored shall not be considered a conviction for purposes of this chapter, unless such pardon, expungement, or restoration of civil rights expressly provides that the person may not ship, transport, possess, or receive firearms.

Although $\$ 922(\mathrm{~g})(1)$ defines its predicate crimes by length of possible imprisonment and not by class, I will follow judicial convention and call these crimes "felonies."

12 United States v. Langley, 62 F.3d 602, 606 (4th Cir. 1995); United States v. Ramos, 961 F.2d 1003, 1005 (1st Cir. 1992), overruled on unrelated grounds by United States v. Caron, 77 F.3d 1, 5 (1st Cir. 1996); United States v. McNeal, 900 F.2d 119, 121 (7th Cir. 1990); United States v. Shunk, 881 F.2d 917, 921 (10th Cir. 1989).

Section $922(\mathrm{~g})(1)$ has survived numerous Commerce Clause challenges brought in the wake of United States v. Lopez, 115 S. Ct. 1624 (1995). See, e.g., United States v. Rawls, 85 F.3d 240, 242-43 (5th Cir. 1996); United States v. Sorrentino, 72 F.3d 294, 296 (2d Cir. 1995); United States v. Bell, 70 F.3d 495, 498 (7th Cir. 1995); United States v. Shelton, 66 F.3d 991, 992 (8th Cir. 1995); United States v. Hanna, 55 F.3d 1456, 1462 \& n.2 (9th Cir. 1995); United States v. Bolton, 68 F.3d 396, 400 (10th Cir. 
defendant specifically knew of his felony status or the interstate nexus appears to be necessary. ${ }^{13}$

Since the governinent generally can prove a defendant's felony status with uncontrovertible docuinentary proof, and show a weapon's interstate connection with unassailable expert testiinony, ${ }^{14}$ the chief, perhaps only, factual issue that the parties will seriously dispute in front of a jury will be possession. Yet even though a defendant's felony status is analytically separate from the other issues in the case, the chances that jurors aware of his criminal record (if they deem it serious) will be overly quick to find possession and convict are all too great. ${ }^{15}$

The route that a juror takes once exposed to such evidence can vary. She might infer that the defendant has a bad character, and from that, assume he would be more likely to possess a gun illegally. ${ }^{16}$ She might consciously or subconsciously demand less of the government, secure that she will have few regrets if a convicted felon is sent "back" to prison, irrespective of his guilt on the pending charge. ${ }^{17}$ Or she might not even tarry on the question of factual guilt, and will vote to convict someone she thinks was not punished enough the first time and/or who may

1995); Deborah Jones Merritt, Commerce!, 94 Mich. L. Rev. 674, 717-19 \& n.183 (1995).

${ }^{13}$ See Langley, 62 F.3d at 606; United States v. Dancy, 861 F.2d 77, 81-82 (5th Cir. 1988).

${ }^{14}$ See, e.g., Rawls, 85 F.3d at 243; United States v. Ware, 914 F.2d 997, 1001-03 (7th Cir. 1990) (ATF agent helpful in determining whether firearm had traveled interstate); United States v. Wallace, 889 F.2d 580, 583-84 (5th Cir. 1989) (ATF agent properly permitted to opine that markings on gun established it had been manufactured by out-of-state company); United States v. Gann, 732 F.2d 714, 724-25 (9th Cir. 1984).

is See Deborah S. Prutzman, Note, Prior Convictions and the Gun Control Act of 1968, 76 Colum. L. Rev. 326, 345 (1976).

${ }^{16}$ See Victor J. Gold, Limiting Judicial Discretion to Exclude Prejudicial Evidence, 18 U.C. Davis L. Rev. 59, 68-69 (1984).

${ }^{17}$ See Richard O. Lempert, Modeling Relevance, 75 Mich. L. Rev. 1021 (1977):

[S]ome may regard a convicted felon as essentially criminal and believe that if he did not commit the crime charged he probably has committed or will commit other crimes. For these reasons the mistaken conviction of those with criminal records is likely to be perceived as less regrettable than the mistaken conviction of individuals thought never to have been in trouble with the law.

Id. at 1039; Harry Kalven \& Hans Zeisel, The American Jury 179 (1966) (if judge admits evidence of an accused's other crimes, jury will likely use a "different ... calculus of probabilities" in deciding whether to convict). 
pose a threat to her community. Whichever route is taken, there is inuch power to the conventional wisdom that "inquiry" into a defendant's prior crimes will "weigh too much with the jury and .... so overpersuade thein as to prejudge one with a bad general record and deny him a fair opportumity to defend against a particular charge."18. This, of course, is the basis for Rule 404, which bars the use of "[e]vidence of other crimes ... to prove the character of a person in order to show action im conformity therewith." 19

One solution to the problem would be flatly to bar the government from proving that the defendant in a felon-in-possession case has a criminal record. But courts have uniformly rejected this approach, and rightfully so. Not even the broadest reading of Rule 403-which generally addresses risks of unfair prejudice - can prevent the prosecution from satisfying its burden of proving an element of the charged offense. Nor have defendants been permitted to separate the felony and possession elements by completely stipulating the felony element out of the case, or by bifurcating the proceeding, because a defendant's status as a felon remains an integral element of the crime. Here, courts have reasoned, the risk to the government could be described im much the same terms as the risks that a defendant faces when the jury learns of his prior felony.

As the First Circuit explained, in overturning a trial court's plan to bifurcate a felon-in-possession trial:

[W] hen a jury is neither read the statute setting forth the crime nor told of all the elements of the crime, it may, justifiably, question whether what the accused did was a crime.... Possession of a firearm by most people is not a crime. A juror who owns or has friends and relatives who own firearms may won-

${ }^{18}$ Michelson v. United States, 335 U.S. 469, 476 (1948).

${ }^{19}$ Fed. R. Evid. 404(b). See Christopher B. Mueller \& Laird C. Kirkpatrick, Evidence $\S 4.11$, at 216-20 (1995); 1 Stephen A. Saltzburg, Michael A. Martin \& Daniel J. Capra, Federal Rules of Evidence Manual 317-19 (6th ed. 1994).

Congress recently relaxed the Federal Rules of Evidence's general prohibition on the use of prior crimes evidence on a propensity theory. See Fed. R. Evid. 413, 414. For perspectives on the wisdom of this change, see the symposiums in the Fordham Urban Law Journal, 22 Ford. Urb. L.J. 265-359 (1995), and the Chicago-Kent Law Review, Symposium on the Admission of Prior Offense Evidence iu Sexual Assault Cases, 70 Chi.-Kent L. Rev. 3 (1994). 
der why [the defendant's] possession was illegal. Doubt as to the criminality of [the defendant's] conduct may influence the jury when it considers the possession element. ${ }^{20}$

Given that nearly half of all American households have at least one firearm, ${ }^{21}$ and that, with certain noteworthy exceptions, ${ }^{2}$ federal and state regulations generally pose hittle obstacle to the possession of such weapons, the government would indeed be handicapped, perhaps fatally, were a jury to perceive a case as a criminal prosecution for mere possession of a firearm. ${ }^{23}$ Here, too, a juror's route might vary. She might take the judge's word that mere possession is criminal, but, having never heard of such an offense herself, be inclimed to cut some slack for the defendant whose only crime was to carry a gun. ${ }^{24}$ She might be-

${ }^{20}$ United States v. Collamore, 868 F.2d 24, 28 (1st Cir. 1989). See also United States v. Jacobs, 44 F.3d 1219, 1222-23 (3d Cir. 1995); United States v. Barker, 1 F.3d 957, 959 (9th Cir. 1993), modified, 20 F.3d 365 (9th Cir. 1994); United States v. Birdsong, 982 F.2d 481, 482 (11th Cir. 1993).

Courts have cited similar reasons when rejecting defense efforts to stipulate the felony element entirely out of $\$ 922(\mathrm{~g})(1)$ prosecutions. See United States v. Gilliam, 994 F.2d 97, 102 (2d Cir.), cert. denied, 510 U.S. 927 (1993); United States v. Bruton, 647 F.2d 818, 825 (8th Cir.) (en banc), cert. denied, 454 U.S. 868 (1981); United States v. Williams, 612 F.2d 735, 740 (3d Cir. 1979), cert. denied, 445 U.S. 934 (1980); United States v. Blackburn, 592 F.2d 300, 301 (6th Cir. 1979); United States v. Brinklow, 560 F.2d 1003, 1006 (10th Cir. 1977), cert. denied, 434 U.S. 1047 (1978).

${ }^{21}$ See James D. Wright, Peter H. Rossi \& Kathleen Daly, Under The Gun: Weapons, Crime and Violence in America 34-35 (1983). If the question is presented as one of individual ownership, the results are consistent. See David Hemenway, Sara Solnick \& Deborah Azrael, Firearms and Community Feelings of Safety, 86 J. Crim. L. \& Criminology 121, 122 (1995) ("[G]un owners comprise almost $30 \%$ of U.S. population."); see also Sourcebook, supra note 9 , at 189 tbls.2.78, 2.79 (35\% of poll respondents in 1995 say they "personally own a gun," $41 \%$ of respondents in 1994 report having a firearm in home).

${ }^{2}$ See, e.g., D.C. Code Ann. $\$ \S 6-2311$ to -2312 (1995); N.Y. Penal Law $\S 265.02$ (McKinney 1989) (felony to possess any loaded gun) and $\S 400.00$ (McKinney Supp. 1996) (no license issued if good cause exists for denial); see also Sourcebook, supra note 9, at 120 tbl.1.110 (surveying state statutory provisions relating to purchase, ownership, and use of firearms).

${ }^{2}$ Data in support of this include the fact that, in Brooklyn, New York, between 1990 and 1993, juries acquitted in state gun possession cases "at an average rate of $56 \%$, in contrast to an overall acquittal rate of approximately $35 \%$ and in sharp contrast to a rate of $28.7 \%$ in narcotics cases during the same period." David N. Dorfman \& Chris K. Ijima, Fictions, Fault, and Forgiveness: Jury Nullification in a New Context, 28 U. Mich. J.L. Reform 861, 886-87 (1995).

${ }^{24}$ See Kalven \& Zeisel, supra note 17 , at $258-85$ (discussing jurors' treatment of cases they deem "de minimis"). 
lieve sucl an apparently sweeping law to be inappropriate, and nullify on that basis. ${ }^{25}$ Or slie miglit be unduly demanding of the government on the possession issue, liaving little fear that a defendant wrongfully acquitted of such a piddling crime would pose any danger to society. ${ }^{26}$

Forced to accept the introduction of some reference to their criminal past and understandably choosing not to rely on cautionary mstructions, ${ }^{27}$ many defendants (particularly those witl convictions for violent crimes) sought to preclude the government from proving the nature of their prior felony by offering to stipulate tliat they liad the requisite felony record. Their efforts were largely successful in a majority of the Circuits. ${ }^{28}$ And the defensive measure will be uniformly available after Old Chief.

\section{B. Old Chief}

Justice Souter's reasoning in Old Chief was straightforward: The availability of "alternative proofs" of a defendant's felony status does not make evidence specifying tlie nature of his prior offense "irrelevant" under the Rules. ${ }^{29}$ Yet a trial judge must consider the existence of such an alternative when balancing

\footnotetext{
${ }^{25}$ See id. at 286-97 (discussing acquittals in cases involving unpopular laws); Wright, Rossi \& Daly, supra note 21, at 241 ("There is very little popular support for an outright ban on private ownership of handguns. . . . Large majorities believe that they have a right to own guns and that the Constitution guarantees that right.").

${ }^{26}$ See Kalven \& Zeisel, supra note 17, at 165 ("Liberation" hypothesis explains interplay between evidence and jury sentiment: "The sentiment gives direction to the resolution of the evidentiary doubt; the evidentiary doubt provides a favorable condition for a response to the sentiment."); Lempert, supra note 17, at 1032 (modeling jury decisionmaking according to regret matrix).

${ }^{27}$ See Miguel Angel Mendez, California's New Law on Character Evidence: Evidence Code Section 352 and the Impact of Recent Psychological Studies, 31 UCLA L. Rev. 1003, 1049 (1984); Roselle L. Wissler \& Michael J. Saks, On the Inefficacy of Limiting Instructions: When Jurors Use Prior Conviction Evidence to Decide on Guilt, 9 Law \& Hum. Behav. 37 (1985); see also Spencer v. Texas, 385 U.S. 554, 575 (1967) (Warren, C.J., dissenting) ("[I]t flouts human nature to suppose that a jury would not consider a defendant's previous trouble with the law in deciding whether he has committed the crime currently charged against him.").

${ }^{23}$ See supra note 3 and accompanying text.

${ }^{29}$ Old Chief, 117 S. Ct. at 649 . See Fed. R. Evid. 401 (defining relevance as "having any tendency to make the existence of any fact that is of consequence to the determination of the action more probable or less probable than it would be without the evidence").
} 
"probative value" against "the danger of unfair prejudice," as required by Rule $403 .^{30}$ "Unfair prejudice," Justice Souter reasoned, would occur were jurors, presented with evidence of a defendant's prior felony, to "generaliz[e] a defendant's earlier bad act into bad character and tak[e] that as raising the odds that he did the later bad act now charged (or, worse, as calling for preventive conviction even if he should be innocent momentarily)."31 The risk of such prejudice will "vary from case to case," but will be particularly great where the prior conviction is "for a gun crime or one similar to other charges in [the] pending case." Under such circumstances, or whenever "the prior conviction is for an offense likely to support conviction on some improper ground," a trial judge would abuse her discretion if she allowed the government to communicate the nature of a defendant's prior felony, notwithstanding his offer to concede that element. ${ }^{33}$ Such a concession, the Court recognized, could not properly be called a "stipulation" in the absence of government consent, but would be fully admissible as an "admission,"34 and, as such, would be a more satisfactory evidentiary alternative under Rule 403.

Justice Souter took the time to respond to the government's invocation of the "familiar" rule "that a criminal defendant may not stipulate or admit his way out of the full evidentiary force of

${ }^{30}$ Fed. R. Evid. 403.
${ }^{31}$ Old Chief, 117 S. Ct. at 650.
${ }^{32}$ Id. at 652 .
${ }^{33}$ Id. at 655 . Although the Court has frequently avowed its confidence that juries will abide by limiting instructions, see, e.g., Shannon v. United States, 512 U.S. 573, 585 (1994); Richardson v. Marsh, 481 U.S. 200, 206 (1987), lower courts have noted that such instructions may not be sufficient when evidence of prior crimes is introduced. See, e.g., Government of Virgin Islands v. Pinney, 967 F.2d 912, 918 (3d Cir. 1992); United States v. DeCastris, 798 F.2d 261, 264 (7th Cir. 1986) (telling jury not to consider prior crimes as evidence of defendant's bad character "is like telling someone not to think about a hippopotamus"). The decision in Old Chief reflects the same skepticism.

${ }^{34}$ Old Chief, 117 S. Ct. at 653 (citing Fed. R. Evid. 801(d)(2)(A) (rule states that "party's own statement in either an individual or a representative capacity" deemed "not hearsay" when offered against that party)). See Black's Law Dictionary 48 (6th ed. 1990) (defining "judicial admissions" as "formal acts done by a party or his attorney in court... for the purpose of dispensing with proof by the opposing party of some fact claimed by the latter to be true"). 
the case as the government chooses to present it." ${ }^{35}$ As a general matter, he conceded the argument's power:

When a juror's duty does seem hard, the evidentiary account of what a defendant has thought and done can accomplish what no set of abstract statements ever could, not just to prove a fact but to establish its human sigmificance, and so to implicate the law's moral underpinnings and a juror's obligation to sit im judgment. Thus, the prosecution may fairly seek to place its evidence before the jurors, as much to tell a story of guiltiness as to support an inference of guilt, to convince the jurors that a guilty verdict would be morally reasonable as much as to point to the discrete elements of a defendant's legal fault. ${ }^{36}$

The prosecution also has an interest, Justice Souter noted, in satisfying juror "expectations about what proper proof should be": "A party seemingly responsible for cloaking something has reason for apprehension, and the prosecution with its burden of proof may prudently demur at a defense request to interrupt the flow of evidence telling the story in the usual way.",37

Having noted the force of these arguments in other contexts, however, the Court found that they had "no application when the point at issue is a defendant's legal status, dependent on some judgment rendered wholly independently of the concrete events of later criminal behavior charged against him.".38 The "events behind the prior conviction" are not "proper nourishment for the jurors' sense of obligation to vindicate the public interest," and "[p]roving status without telling exactly why that status was imposed leaves no gap in the story of a defendant's subsequent criminality. ${ }^{, 39}$

These assumptions about how a jury will approach a felon-inpossession case are a bit disingenuous. If, as Pennington and Hastie have persuasively suggested, jurors "impose a narrative story organization on trial information, ${ }^{, 40}$ it would be odd in-

\footnotetext{
${ }^{35}$ Old Chief, 117 S. Ct. at 653.

${ }^{36}$ Id. at 653-54.

${ }^{37} \mathrm{Id}$. at 654.

${ }^{38}$ Id. at 654-55.

39 Id. at 655.

* Nancy Pennington \& Reid Hastie, The Story Model for Juror Decision Making, in Inside the Juror: The Psychology of Juror Decision Making 192, 194 (Reid Hastie
} 
deed if this story did not comprehend that which makes gun possession a federal crime, or a crime at all. In a country where many believe there to be a fundamental, even constitutional, right to gun possession, ${ }^{41}$ a jury's decision about whether convicting a prior felon for possessing a gun is "morally reasonable" will inevitably turn, at least in part, on the nature of that prior felony. Indeed, Justice Souter admits as much when he observes that "an extremely old conviction for a relatively minor felony that nevertheless qualifies under the statute might strike many jurors as a foolish basis for convicting an otherwise upstandimg member of the community of otherwise legal gun possession., ${ }^{42}$

When jurors are not told what a defendant's prior felony was, from what will they construct the story of his criminality? One source of inferences might be the circumstances of the charged firearms possession. ${ }^{43}$ The prior felony of a defendant arrested at night near a gas station with a concealed weapon "must" be robbery. ${ }^{44}$ If the facts of the arrest suggest some connection with

ed., 1993) (emphasis omitted). See also Reid Hastie, Steven D. Penrod \& Nancy Pennington, Inside the Jury 15-36 (1983); Nancy Pennington \& Reid Hastie, A Cognitive Theory of Juror Decision Making: The Story Model, 13 Cardozo L. Rev. 519 (1991); W. Lance Bennett \& Martha S. Feldman, Reconstructing Reality in the Courtroom: Justice and Judgment in American Culture (1981) (arguing that jurors use storytelling techniques to interpret information presented in criminal trials).

${ }^{41}$ See Staples v. United States, 511 U.S. 600, 610 (1994) ("the fact remains that there is a long tradition of widespread lawful gun ownership by private individuals in this country"); Sourcebook, supra note 9, at 193 tbl.2.84 (60\% of people polled in 1993 said there "should not be a law that would ban the possession of handguns except by the police and other authorized persons").

42 Old Chief, 117 S. Ct. at 652-53 n.8.

${ }^{43}$ One of the few jury deliberations ever filmed and televised involved a Wisconsin trial of a defendant on state felon-in-possession charges. Frontline \#410: Inside the Jury Room (PBS television broadcast, Apr. 8, 1986) [hereinafter Inside the Jury Room]. Although defense counsel conceded all the elements of the offense in his opening, the jury ultimately acquitted. In their deliberations, jurors focused on the sympathetic circumstances of the defendant's possession. A man of limited intelligence, he wanted to be a private investigator and believed from watching his favorite television program that all one needed to become a private investigator was to carry a pistol. During the taped parts of the trial and deliberations, no one made any mention of the nature of the defendant's prior felony. See Dorfman \& Iijima, supra note 23 , at $880-81$ (discussing the documentary).

4 These facts come from a recent case in which a $\$ 922(\mathrm{~g})(1)$ defendant raised the oddest claim of prejudice I have yet found. In United States v. Wiman, 77 F.3d 981 (7th Cir. 1996), defendant argued that the trial court should not have excluded evidence that he was carrying burglary tools when he was arrested at night near a gas station. Unaware of this evidence, he claimed, jurors might have assumed that he 
drug dealing, his prior "surely was" a narcotics conviction. The prior crime of the $\S 922(\mathrm{~g})(1)$ defendant also charged with bank robbery might be bank robbery. ${ }^{45}$

But a far more dangerous source of inferences-dangerous because of their systematic impact-will be the defendant's personal characteristics: his race, gender, socio-economic status, or some combination thereof. ${ }^{45}$ Presented with a young black male, for example, and told that he has been convicted of some unspecified crime, jurors will be far more likely to decide that the prior crime was, say, robbery or drug dealing, as opposed to fraud. ${ }^{47}$ And the past transgression of a middle-aged middle-

was involved in a botched robbery, which is worse than burglary. The Seventh Circuit wondered how this evidence could have made any difference to the jury's consideration of the $\$ 922(\mathrm{~g})(1)$ charge, and noted that defendant could have offered the proof himself.

${ }^{45}$ Cases in which a defendant faces multiple counts that include a $\S 922(\mathrm{~g})(1)$ charge raise special issues of prejudice. The jury hearing evidence of other serious crimes will be inclined to assume that the defendant's prior felony was a serious offense and consequently be more prone to convict on the gun count. And knowledge, acquired from the $\$ 922(\mathrm{~g})(1)$ count, that the defendant already has a felony record can make the jury more ready to convict on the joined counts. These dangers have led courts to mandate the severance of $\$ 922(\mathrm{~g})(1)$ counts. See United States v. Dockery, 955 F.2d 50, 54-56 (D.C. Cir. 1992). Because I suspect that joined counts, when present, play a larger role in jury speculations as to the nature of an unspecified prior felony than do defendant characteristics, much of the discussion herein focuses on cases in which the $\S 922(\mathrm{~g})(1)$ charge is the sole count before the jury.

${ }^{46}$ See Norman J. Finkel, Commonsense Justice: Jurors' Notions of the Law 72 (1995) ("[P]rospective jurors are likely to have in their memories representations of crimes, actors, and outcomes: images of what certain crimes look like, the types of people who commit such crimes, and the types of harm that ensue." (citations omitted)).

Once a juror decides what a defendant's prior felony must have been, the details of that crime will quickly come to mind, even (or perhaps particularly) in the absence of any evidence. See id. at 72-74; Loretta J. Stalans, Citizens' Crime Stereotypes, Biased Recall, and Punishment Preferences in Abstract Cases: The Educative Role of Interpersonal Sources, 17 Law \& Hum. Behav. 451 (1993); Vicki L. Smith, Prototypes in the Courtroom: Lay Representations of Legal Concepts, $61 \mathrm{~J}$. Personality \& Soc. Psychol. 857 (1991).

${ }^{47}$ See Michael Sunnafrank \& Norman E. Fontes, General and Crime Related Racial Stereotypes and Influence on Juridic Decisions, 17 Cornell J. Soc. Rel. 1 (1983); see also Adeno Addis, "Hell Man, They Did Invent Us": The Mass Media, Law, and African-Americans, 41 Buff. L. Rev. 523 (1993) (arguing that the mainstream media produces a negative image of African Americans); Cynthia Kwei Yung Lee, Race and Self-Defense: Toward a Normative Conception of Reasonableness, 81 Minn. L. Rev. 367, 402-23 (1996) (discussing the stereotype of African Americans as criminals); Sheri Lynn Johnson, Black Innocence and the White Jury, 83 Mich. L. Rev. 
class white defendant can be presumed to be quite benign (albeit technically illegal). Instructions that jurors not speculate as to a defendant's prior crime will not prevent such stereotyping. They will simply drive it underground by deterring jurors from discussing the matter during deliberations. ${ }^{48}$

\section{The Prosecutor's Purpose}

The rule in Old Chief thus tends to put the prosecution at a disadvantage in all cases involving defendants with criminal records that jurors would take seriously were they to learn of them. These are the cases where defendants will offer admissions to a generic felony with alacrity. Defendants whom jurors incorrectly presume benign will do best, for the jury will now never think otherwise. Those whose odious records conform to the stereotypes now driving juror speculations will benefit marginally from the uncertainty created by the rule, if jurors are less inflamed by speculation about the prior crimes than they would be if presented with certain proof.

Although the Court appears willfully blind to the effects of its rule on the government's prospects at trial, Justice Souter's analysis is far more convincing when read, not as description of jury behavior, but as a determination that prosecutors must accept the consequences of a statute that reaches far too many cases that do not comport with popular notions of criminality. The Court's assessment of what constituted "proper nourishment for the jurors' sense of obhigation to vindicate the public imterest ${ }^{\$ 49}$ ends up turning on how Congress chose to define the public interest:

Congress ... has made it plain that distinctions among generic felomes do not count for this purpose; the fact of the quabifying conviction is alone what matters under the statute. "A defen-

1611, 1633 (1985) (discussing Sunnafrank and Fontes's studies showing that certain crimes were more frequently attributed to African Americans); Sheri Lynn Johnson, Racial Imagery in Criminal Cases, 67 Tul. L. Rev. 1739, 1751 (1993) (noting how, in summations, some prosecutors use the "image of African Americans as more violent and more criminal than whites").

${ }^{48}$ Cf. Hastie, Penrod \& Pennington, supra note 40, at 231-32 (finding that evidence stricken from record will generally not be discussed in deliberations but may still have impact).

${ }^{49}$ Old Chief, 117 S. Ct. at 655. 
dant falls within the category simply by virtue of past conviction for any [qualifying] crime ranging froin possession of short lobsters, see 16 U.S.C. $\$ 3372$, to the most aggravated inurder." The most the jury needs to know is that the conviction admitted by the defendant falls within the class of crimes that Congress thought should bar a convict from possessing a gun....

Jurors might indeed take $\S 922(\mathrm{~g})(1)$ prosecutions less seriously, and consequently be less likely to return guilty verdicts, when precluded from the learning the particulars of defendants' prior records. But if Congress is going to legislate so broadly, the Court suggests, perhaps $\S 922(\mathrm{~g})(1)$ offenses ought to be taken less seriously. ${ }^{51}$

In the context of individual cases, the handicap that the Court places on the government by refusing to recognize the eviden-

so Id. (alterations in original) (citations omitted) (quoting United States v. Tavares, 21 F.3d 1, 4 (1st Cir. 1994) (en banc)). Here, the Court echoed the First Circuit's point in Tavares:

The [felony] status element is a discrete and independent component of the crime, a requirement reflecting a Congressional policy that possession of a firearm is categorically prohibited for those individuals who have been convicted of a wide assortment of crimes calling for a punishment of over a year's imprisonment.... The predicate crime is significant only to demonstrate status, and a full picture of that offense is-even if not prejudicial-beside the point.

Tavares, 21 F.3d at 4 . It was the First Circuit that first made the lobsterman the poster-boy $\$ 922$ (g) defendant. In Scarborough v. United States, 431 U.S. 563 (1977), Justice Stewart had his own favorite: the bookkeeper who owns a hunting rifle, gets convicted of embezzlement, and fails to relinquish possession of his firearm. Id. at 579-81 n.1 (Stewart, J., dissenting).

${ }^{51}$ The care with which Congress legislates in this area was most recently shown in the September 30, 1996 passage of a provision that extended $\S 922(\mathrm{~g})$ 's ban on convicted felons' possession of firearms to include individuals with prior misdemeanor convictions for domestic violence. Omnibus Consolidated Appropriations Act of 1997, Pub. L. No. 104-208, § 658, 110 Stat. 3009-371 to -372 (1996) (codified at 18 U.S.C.A. \& $922(\mathrm{~g})(9)$ (West 1997)). Soon thereafter, local police departments complained that enforcement of the law would require more than 60,000 police officers to turn in their weapons. Business Wire, New Law Could Force More Than 60,000 Cops to Turn in Their Guns, Survey Shows, Feb. 25, 1997, available in WESTLAW, Allnewsplus File. See also Naftali Bendavid, A Political Gunfight, Legal Times, Mar. 3, 1997, at 19 (police leaders estimate that "several hundred cops" affected); Roberto Suro \& Philip P. Pan, Law's Omission Disarms Some Police: Domestic Violence Act Has Some Officers Hanging Up Their Guns, Wash. Post, Dec. 27, 1996, at A16 (describing how blanket exception for official use was dropped during rush to pass appropriations legislation that included the new domestic violence provision). Two bills to amend the provision are now pending in the House, each supported by various police organizations. Bendavid, supra, at 19. 
tiary disadvantages created by generic defense concessions is thus understandable. A hittle odd, perhaps, since the same logic would counsel a rule preventing the prosecution from telling the jury about the quantity of drugs in a charged drug transaction. ${ }^{52}$ But it may be justifiable (if one resorts to the kind of deterrent logic that supports constitutional exclusionary rules). Far less justifiable are the disadvantages that the Court's approach threatens to impose on $\S 922(\mathrm{~g})(1)$ defendants. The extent of this threat in the individual case largely turns on whether defendants will be permitted to inform juries about the nature of their prior felonies if they so choose-in other words, on whether the analysis in Old Chief will be applied asymmetrically or symmetrically.

If he has this option, the defendant whose prior conviction was for some "technical, non-violent or white collar crime"s53 and who was prejudiced because the jury did not learn these specifics can fault only his lawyer, not the Court. And the Court certainly assumed a rule of defendant control. Referring to that "extremely old conviction for a relatively minor felony," which would "strike many jurors as a foolish basis for convicting an otherwise upstanding" defendant, Justice Souter noted: "Since the Government could not, of course, compel the defendant to admit formally the existence of the prior conviction, the Government would have to bear the risk of jury nullification, a fact that might properly drive the Government's cliarging decision."\$s4

This reasoning misperceives the government's evidentiary options. A prosecutor wishing to avoid telling the jury about a defendant's piddling prior conviction will not be able to obtain a stipulation or judicial admission froin an unwilling defendant. He can, however, find other ways of proving that a defendant lias a prior felony without alerting the jury to its nature. If imterrogation responses or court, prison, or parole documents do

\footnotetext{
's2 Quantity is not an element of the federal narcotics distribution offense, but goes only to sentencing. See United States v. Campuzano, 905 F.2d 677, 679 (2d Cir.), cert. denied, 498 U.S. 947 (1990); United States v. Brown, 887 F.2d 537, 540 (5th Cir. 1989). I know of no case where a court barred the government from proving the quantity of drugs, and I do not imagine the absence of such a precedent can be attributed to the failure of any defendant ever to concede that a charged possession or distribution did involve drugs.
}

${ }^{53}$ Tavares, 21 F.3d at 4.

ss Old Chief, 117 S. Ct. at 652-53 n.8. 
not already provide this kind of generic evidence (perhaps with references to specific felonies edited out), the government might start generating documents that do-documents admissible as "official records." A defendant could not fairly coinplain that the imformation thus conveyed is incoinplete or misleading. Nor could he necessarily count on being able to tell the jury about his felony during his own case: A trial judge adhering to the logic of Old Chief - and to the approach of the First Circuit in United States $v$. Tavares ${ }^{56}$ that the Supreme Court found so persuasive ${ }^{57}$-would say that such information, albeit inarginally "relevant," poses an unacceptable risk of prejudice to the government. Trial judges precluding defense proof on this issue will presumably rely on Old Chief s pronouncement that the issue of legal status is binary, not requiring "evidentiary depth." In short, there is nothing in Old Chief to prevent lower courts from applying the decision symmetrically, other than the Court's wishful thinking.

The consequences of a regime im which the governinent, when it suits its purposes, can prevent defendants from telling about their prior felomes, are particularly troubling. A prosecutor is most likely to pursue that tactic where a defendant's past felony is relatively benign, and will profit most where jurors' stereotypes are most pejorative. The resulting disadvantage to defendants cannot be excused by pointing to statutory overbreadth.

Here endeth the standard evidentiary analysis, focusing, as most such analyses do, on the effects of the Court's rule on a range of hypothetical cases. Yet some of the foregoing hypotheticals inay be beside the point as a practical niatter. What difference does it inake, for example, if Old Chiefs reasoning is susceptible to symmetrical apphication, if the government never brings $\S 922(\mathrm{~g})(1)$ cases against defendants with relatively in-

\footnotetext{
ss Fed. R. Evid. 803(8).
}

56 21 F.3d 1 (1st Cir. 1994) (en banc).

"7 The Tavares court reasoned that to allow either side to raise or reduce the stakes of a $\$ 922(\mathrm{~g})(1)$ prosecution by alluding to the nature of a defendant's prior felony would subvert congressional policy by replacing the "neutral role intended to be played by the prior felony element" with a "two-tier system of guilt determination." Id. at 4.

ss Old Chief, 117 S. Ct. at 654. 
nocuous records? This raises a question that transcends evidence doctrine: Will the government avoid prosecuting these defendants? And if it doesn't prosecute them, why not? What discourages it from doing so? Or, to be more precise, what factors offset the consequences of a regime that endeavors to bleach out differences among § 922(g)(1) defendants? One can go further and ask more generally about the significance of all such evidentiary rules in our criminal justice system. Certainly, they affect the proof that jurors hear at trial and, presumably, the verdicts they reach. By extension, they presumably affect negotiated dispositions that turn, to some degree, on the likelihood of the government's success at trial. But do they have more systemic consequences?

\section{OF EVIDENTIARY RULES AND PROSECUTORIAL DISCRETION}

Regardless of how Old Chief affects defendants in individual cases, and regardless of whether the decision is read to permit defendant control over the introduction of prior felony information, it will have no systematic effects on defendant incentives. Defendants, after all, are one-shot players, interested only in achieving immediate, favorable results in their respective cases. But to the extent this rule, indeed any evidentiary rnle, affects a prosecutor's chances of success, one might expect its mipact to be transferred onto case selection decisions. Perhaps because the issue crosses the artificial border between Evidence and Criminal Procedure, all too little attention is generally paid to the influence that proof restrictions can, or should, have on the exercise of prosecutorial discretion.

\section{A. Prosecutorial Professionalism and Accountability}

Every prosecuting office-and every prosecutor, to some extent-faces a daunting range of targets against which to deploy relatively scarce resources. ${ }^{59}$ Some of the decisions are quite

${ }^{59}$ See Wayne R. LaFave, The Prosecutor's Discretion in the United States, $18 \mathrm{Am}$. J. Comp. L. 532, 533-34 (1970). The options from among which a prosecutor must choose are shaped by such constraints as the crime rate, the size of the jurisdiction's population, and his office's budget allocation. See Joan E. Jacoby, The Charging Policies of Prosecutors, in The Prosecutor 75, 77-78 (William F. McDonald ed., 1979). 
general: White collar criminals or violent offenders? Higher level drug traffickers or street peddlers? With a broadly defined pohicy agenda set, the finer-grained questions will emerge: Which street robbers are most deserving of pumshment? Which illegal gun cases? The response to a particular case need not be binary. Prosecution can be declined. Prosecution might be initiated, but with little commitment of investigative or adjudicative resources. Or the maximum penalty can be pursued hotly. As a practical matter, such choices are obviously not committed solely to the discretion of prosecutors. Indeed, the most important factors in determining who gets prosecuted for what are the decisions of supervisory and line personnel im police departınents or investigative agencies. But once those enforcement entities have done their winnowing, the scope of prosecutorial discretion reınains immense. ${ }^{60}$

On what basis should prosecutors makes these choices? We are somewhat of two minds on this point, subscribing to ideals of professionalisin and pohitical responsibility that sometimes conflict.

\section{Professionalism}

On one hand, we celebrate the professional independence of prosecutors. We expect them to set their priorities based on such considerations as the responsiveness of a social problem to criminal sanctions, the nature of the harm, ${ }^{61}$ and the maximiza-

\footnotetext{
${ }^{6}$ See James Eisenstein, Counsel for the United States: U.S. Attorneys in the Political and Legal Systems 156-57 (1978); W. Boyd Littrell, Bureaucratic Justice: Police, Prosecutors, and Plea Bargaining (1979) (discussing role of discretion in otherwise bureaucratic administration of justice); see also $\mathrm{H}$. Richard Uviller, Tempered Zeal: A Columbia Professor's Year on the Streets with New York City Police 20-26 (1988) (describing police attitudes towards discretionary calls by prosecutors, including specifically decisions not to prosecute); Joseph Goldstein, Police Discretion Not to Invoke the Criminal Process: Low-Visibility Decisions in the Administration of Justice, 69 Yale L.J. 543, 554-55 n.20, 560 n.28 (1960) (discussing influence of prosecutorial decisions on police decisionmaking).

${ }^{6}$ See Stephen J. Schulhofer, Criminal Justice Discretion as a Regulatory System, 17 J. Legal Stud. 43, 65 (1988) ("To minimize the social cost of crime, the prosecutor cannot simply attempt to minimize the total number of crimes; she must evaluate the harm associated with each offense and determine the mix of prosecutions that will minimize the total quantum of harm."); ABA Standards for Criminal Justice § 3-3.9(b)(ii)
} 
tion of deterrence. ${ }^{62}$ Criminal sanctions are blunt instruments, and for many technical transgressions, the better approach is either diversion or simple declination. Prosecutors thus emerge as mediators between phenomenally broad legislative pronouncements ${ }^{63}$ and the equities of individual cases, and as technical judges of when evidence is sufficient to proceed. Politics should have nothing to do with the prosecutorial process, and we condemn the ambitious prosecutor suspected of "pandering" to public opinion in her selection of cases. ${ }^{64}$ Indeed, after they decide to pursue charges, prosecutors are expected to maintain an extraordinary degree of professional perspective, to serve as "Ministers of Justice" even as they engage in advocacy.

(1986) (prosecutor may properly consider "extent of the harm caused by the offense") [hereinafter ABA Standards].

${ }^{62}$ Frank H. Easterbrook, Criminal Procedure as a Market System, 12 J. Legal Stud. 289, 295-96 (1983) (prosecutor "attempts to obtain the maximum deterrence from his available resources... by bringing new prosecutions until the marginal deterrence available from investing extra resources in a given prosecution is the same as the return available from investing in some other prosecution"); see William M. Landes, An Economic Analysis of the Courts, 14 J.L. \& Econ. 61, 63 (1971) (prosecutor seeks "to maximize the expected number of convictions weighted by their respective [sentences] ... subject to a constraint on the resources or budget available to his office" (footnote omitted)); cf. Robert L. Misner, Recasting Prosecutorial Discretion, $86 \mathrm{~J}$. Crim. L. \& Criminology 717 (1996) (arguing that exercise of prosecutorial discretion should be tied to availability of prison resources).

${ }^{63}$ See ABA Standards, supra note 61, § 3-3.9 commentary, at 3-56 (referring to "breadth of criminal legislation").

${ }^{*}$ See H. Richard Uviller, Virtual Justice: The Flawed Prosecution of Crime in America 163 (1996) (finding "the political factor in the calculation of discretion to be profoundly offensive, bordering on unethical"); see also Michael W. Dolan, Political Influence on the Department of Justice: Are the Pressures Only External?, 9 J.L. \& Pol. 309, 312 (1993) ("Rare is the federal prosecutor who has not been described by his or her enemies as politically ambitious ...."). When Rudolph Giuliani was United States Attorney for the Southern District of New York, his worst critics would accuse him of being "political." See, e.g., William Safire, Guarding the Guardians, N.Y. Times, Feb. 24, 1986, at A15 (alluding to "political prosecutors who will do anything for publicity"); Teri Agins, Prosecutor Giuliani, New York's Top Crimebuster, Aggressively Courts Convictions, Media Attention, Wall St. J., May 13, 1986, at 64.

¿s Perhaps the most quoted invocation of this ideal comes from Justice Sutherland:

[The prosecutor] is in a peculiar and very definite sense the servant of the law, the twofold aim of which is that guilt shall not escape or innocence suffer.... It is as much his duty to refrain from improper methods calculated to produce a wrongful conviction as it is to use every legitimate means to bring about a just one.

Berger v. United States, 295 U.S. 78, 88 (1935). 
The call for professionalism first came in the 1920s and 1930s from those who decried the corruption and favoritism infecting so many prosecutorial offices. ${ }^{66}$ The ideal is thus, at least in part, negative-one of insulation from narrow interest groups and corrupt influences. ${ }^{67}$ But it has developed far further, into a robust behef, as an affirmative matter, that independent-minded prosecutors are well-placed to divine the public interest, and to harmonize ill-defined legislative pohicies with principles of individualized justice. ${ }^{68}$ The notion has withstood decades of wellreasoned calls for guidelines and rulemaking to cabin broad prosecutorial discretion. ${ }^{69}$ And it remains embedded, even as the

\footnotetext{
${ }^{60}$ See, e.g., Raymond Moley, Politics and Criminal Prosecution 25 (1929) (In some recent scandals, "[p]rosecution was feeble and incompetent because prosecutors' offices were political agencies rather than law offices. Insidious relationships existed between shady characters and public officials because votes and party funds were involved."); see also Misner, supra note 62 , at 730 n.80 (citing similar critiques from 1920 s and 1930s).

6 In his oft-quoted speech made while he was Attorney General, Robert Jackson explained "why the prosecutor should have, as nearly as possible, a detached and impartial view of all groups in his community." Morrison v. Olson, 487 U.S. 654, 727 (1988) (Scalia, J., dissenting) (quoting Robert Jackson, The Federal Prosecutor, Address at the Second Annual Conference of United States Attorneys (Apr. 1, 1940)).

see ABA Standards, supra note 61, \$3-3.9 commentary, at 3-56 ("The public interest is best served and evenhanded justice best dispensed not by the mechanical application of the 'letter of the law,' but by a flexible and individualized application of its norms through the exercise of a prosecutor's thoughtful discretion."); Frank W. Miller, American Bar Foundation, Prosecution: The Decision to Charge a Suspect with a Crime 154 (Frank J. Remington ed., 1969) ("With rare exceptions, legislatures and appellate judges officially approve of this allocation of power to prosecutors ....").

"See, e.g., Kenneth Culp Davis, Discretionary Justice: A Preliminary Inquiry 188214 (1969); Norman Abrams, Internal Policy: Guiding the Exercise of Prosecutorial Discretion, 19 UCLA L. Rev. 1 (1971); Charles D. Breitel, Controls in Criminal Law Enforcement, 27 U. Chi. L. Rev. 427 (1960); James Vorenberg, Decent Restraint of Prosecutorial Power, 94 Harv. L. Rev. 1521 (1981).

Legislators' aversion to taking more control in this area presents an interesting public choice question, particularly in the federal context. Much criminal legislation may stem from legislators' desire to pander to popular opinion, particularly in the wake of some infamous crime. See Sanford $\mathrm{H}$. Kadish, Comment, The Folly of Overfederalization, 46 Hastings L.J. 1247, 1248 (1995). But why write laws with a generality that places such power in the Executive's hands? Perhaps the explanation has something to do with legislators' desire to insulate themselves from those on whom the costs of criminal enforcement fall heaviest, see Peter $\mathrm{H}$. Aranson, Ernest Gelhorn \& Glen O. Robinson, A Theory of Legislative Delegation, 68 Cornell L. Rev. 1, 57-58 (1982), or to avoid the opportunity costs of legislative specification, see Dan M. Kahan, Is Chevron Relevant to Criminal Law?, 110 Harv. L. Rev. 469, 475 (1996) ("[T]ime spent enacting criminal legislation necessarily comes at the expense
} 
proliferation of substantive criminal enactments and the use of sentencing guidelines have vastly increased prosecutorial power. ${ }^{70}$

\section{Accountability}

Yet for all the apparent confidence in the judgment of the professionals, the idea that prosecutors should be broadly responsive to the concerns of their community also runs deep. Where reasonable minds might differ on how prosecutorial re-

of time that could be spent enacting legislation sought by small, highly organized interest groups, which are more likely than the public at large to reward legislators for benefits conferred and to punish them for disabilities imposed."). In addition, vagueness allows the evasion of tough legislative choices. See Charles $R$. Wise, The Dynamics of Legislation 178 (1991). Yet none of these hypotheses fully explains, for example, the sustained, albeit fruitless, attention Congress gave to the monumental task of revising the entire federal criminal code in the 1970s, the extent of congressional activity on sentencing issues, see, e.g., Gary T. Lowenthal, Mandatory Sentencing Laws: Undermining the Effectiveness of Determinate Sentencing Reform, 81 Cal. L. Rev. 61 (1993); William Spade, Jr., Beyond the 100:1 Ratio: Towards a Rational Cocaine Sentencing Policy, 38 Ariz. L. Rev. 1233 (1996), occasional congressional investigations into allegedly inappropriate prosecutorial leniency to certain white collar defendants, see, e.g., Theodora Galacatos, Note, The United States Department of Justice Environmental Crimes Section: A Case Study of Inter- and Intrabranch Conflict Over Congressional Oversight and the Exercise of Prosecutorial Discretion, 64 Fordham L. Rev. 587, 612-28 (1995), or why the breadth of criminal statutes does not seem to turn on the political power of the groups most likely to be affected. It is particularly remarkable that Congress continues to legislate so broadly at a time when the prevalence of crime control rhetoric makes calls for leniency in particular cases or the use of purse strings politically difficult. In other contexts, the legislator who supported a broad delegation of authority to an executive agency can later seek credit for intervening with the "bureaucrats." See Glen O. Robinson, American Bureaucracy: Public Choice and Public Law 77 (1991) (noting suggestion "that the creation of administrative agencies with delegated power enhances the legislator's opportunity for vote-winning casework"). But the political costs of intervening to protect a petitioner from criminal prosecution are generally prohibitive. See Suzanne Weaver, Decision to Prosecute: Organization and Public Policy in the Antitrust Division 151-60 (1977) (overt legislative interference in prosecutorial decisionmaking perceived as too politically dangerous, and lower-visibility efforts rare for same reason).

One short answer may be that the public might blame legislators for failing to criminalize conduct it condemns, but will blame only prosecutors for bringing charges in a marginal case. Given this dynamic, legislators will always be safer if they err on the side of overinclusion. The longer answer must explain how these assumptions about prosecutorial power arose in the first place.

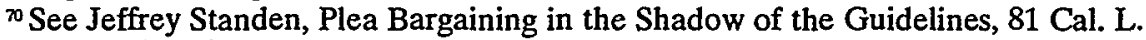
Rev. 1471 (1993); William J. Stuntz, The Uneasy Relationship between Criminal Procedure and Criminal Justice, 107 Yale L.J. _ (forthcoming 1997) (on file with the Virginia Law Review Association). 
sources might be deployed, community preferences are thought to be critical. Even though a professional prosecutor residing in the jurisdiction she serves inay share the concerns of its citizenry, ${ }^{71}$ soine formal inechanisin is thought necessary to ensure that the "people" have a voice in how she deploys resources in their name. ${ }^{33}$ That is why most state and local jurisdictions originally chose to make their chief prosecutors elected officials, ${ }^{74}$ and presuunably why most ${ }^{75}$ of those offices remain elective. ${ }^{76}$ It

"See Eisenstein, supra note 60 , at 198 ("[The] participation [of U.S. attorneys] in the
life of the community, a participation that continues after working hours and on week-
ends and which will continue in the years after they leave the U.S. attorney's office,
practically guarantees that if the dominant political stratum agrees on a policy issue, the
U.S. attorney will share these views." But this mechanism "does not provide guid-
ance... on what to do in specific situations.").
"State prosecutions are generally styled as cases of "The People" against the named
defendant. Federal prosecutions name "The United States" as the plaintiff.
"See James N. Johnson, The Influence of Politics upon the Office of the American
Prosecutor, 2 Am. J. Crim. L. 187, 190-91 (1973) (discussing public support for pop-
ular election of prosecutors). Prosecutors and attorneys general are characterized as
"representatives" under the Voting Rights Act when they are subject to elections. See Chisom v. Roemer, 501 U.S. 380 (1991).

In this sense, we are far less "ambivalent" about the election of prosecutors than we are about the election of judges. See Louis Michael Seidman, Ambivalence and Accountability, 61 S. Cal. L. Rev. 1571 (1988) (describing contradicting defenses of judicial independence); Ruth Gavison, The Implications of Jurisprudential Theories for Judicial Election, Selection, and Accountability, 61 S. Cal. L. Rev. 1617 (1988) (discussing theories of law in relation to judicial accountability); cf. Young v. United States ex rel. Vuitton et Fils S.A., 481 U.S. 787, 807 (1987) ("The requirement of a disinterested prosecutor is consistent with our recognition that prosecutors may not necessarily be held to as stringent a standard of disinterest as judges.").

${ }^{44}$ Kathryn Abrams has observed that:

The decision to make state prosecutors elective, which came at the same time as the move to elect state judges, reflects many of the same judgments: a Jacksonian-inspired belief in the importance of popular accountability, and a belief that such accountability can be reconciled with the need for independence and meritorious performance of duty without completely submerging the latter values.

Kathryn Abrams, Relationships of Representation in Voting Rights Act Jurisprudence, 71 Tex. L. Rev. 1409, 1425 n.83 (1993). See Joan E. Jacoby, The American Prosecutor: A Search for Identity 19-28 (1980).

${ }^{75}$ See John M. Dawson, Steven K. Smith \& Carol J. DeFrances, U.S. Dep't of Justice, Prosecutors in State Courts, 1992, at 2 (1993) (more than 95\% of state and local chief prosecutors are elected).

${ }^{76}$ The continued reliance on the political process for selecting chief prosecutors is particularly noteworthy in light of the trend toward insulating police management and judicial selection from electoral politics. See Alan Edward Bent, The Politics of 
also may explain-or at least justify-the significant, often dispositive, influence that state and local politics can have over the appointment of United States attorneys. ${ }^{7}$

To be sure, the idea of a prosecutor picking targets simply to please her electorate is repugnant (save perhaps in some exceptional cases). ${ }^{78}$ But so is the notion of an official never being held accountable for her judgment calls, inade in the name of the people, about what policies will best serve the community. ${ }^{79}$

Law Enforcement: Conflict and Power in Urban Communities 64-66, 155 (1974); Albert J. Reiss, Jr., The Police and the Public 186-89 (1971) (describing how increased bureaucratization of police forces has made them less responsive to civic and political power); see also Misner, supra note 62, at 766 ("The movement toward appointed judges, non-partisan selected judges, or judges appointed and then subject to a vote of retention (the 'Missouri Plan') have [sic] not found analogous developments in the election of local prosecutors.").

$\pi$ See Eisenstein, supra note 60, at 35-53; see also Morrison v. Olson, 487 U.S. 654, 728 (1988) (Scalia, J., dissenting) ("Under our system of government, the primary check against prosecutorial abuse is a political one."). But see Eisenstein, supra note 60 , at 194-95 (compared to local prosecutors, U.S. attorneys have considerable independence from local politics); cf. Griffin B. Bell \& Daniel J. Meador, Appointing United States Attorneys, 9 J.L. \& Pol. 247 (1993) (arguing that vesting Attorney General with complete control over selection of U.S. attorneys would remove influence of local politics and therefore be beneficial).

${ }^{78}$ Absolutes are difficult here. Although the federal government, as a matter of law, is free to prosecute those acquitted in state court of crimes that can be recharacterized as federal offenses, see Abbate v. United States, 359 U.S. 187 (1959), exercises of that power, in the absence of state corruption, are exceedingly rare, see Daniel C. Richman, Bargaining About Future Jeopardy, 49 Vand. L. Rev. 1181, 1199 (1996). One who supports the recent federal prosecutions in the Rodney King beating case and the Crown Heights murder case (as I do) is hard pressed to find any neutral principle (other than respect for the popular will) that distinguishes these cases from the universe of similar "unjust" acquittals that were not pursued. See Editorial, The Right to Walk a Brooklyn Street, N.Y. Times, Aug. 13, 1994, at 20 (commending Attorney General Reno for "respond[ing] to community anger" by pursuing federal prosecution in Crown Heights case). Dressing this rationale up by pointing to the need to ensure popular confidence in the judicial system does not change the point.

"Defining a prosecutor's relevant "community" may occasionally be difficult. Witness the recent controversy in New York City after Angel Diaz was charged with first degree murder in the death of a police officer: Governor George Pataki had just been elected on a platform that included the reinstatement (and regular use) of the death penalty. Bronx District Attorney Robert Johnson had just been reelected after making his opposition to capital punishment clear. When Johnson failed to show sufficient enthusiasm for the death penalty in the case to satisfy Pataki, the governor superseded Johnson and ordered the state's attorney general to preside over the prosecution. See Rachel L. Swarns, Prosecutor Resists Pataki Pressure on Death Penalty, N.Y. Times, Mar. 21, 1996, at B1; Jan Hoffman, Death Penalty Raises Issue of Obligation of Prosecutor, N.Y. Times, Mar. 17, 1996, at 33. The conflict somewhat 
Accountability may be important for all public servants in a democracy, but it is of particular significance for an official cliarged witl selecting targets for "community condemnation."

The problem, lowever, is that even direct elections are not likely to prove an effective means of giving prosecutors guidance as to a community's enforcement priorities or of holding them accountable for the discretionary decisions that they liave already made. As Kennetli Davis noted:

The reality is that nearly all [the prosecutor's] decisions to prosecute or not to prosecute ... and nearly all his reasons for decisions are carefully kept secret, so that review by the electorate is nonexistent, except for the occasional case that happens to be publicized. The plain fact is that more than ninetenths of local prosecutors' decisions are supervised or reviewed by no one.

Many elections for chief prosecutor are not even contested. ${ }^{82}$ Those that are may be fouglit on whetlier a specific type of crime sliould be prosecuted, ${ }^{83}$ whether a inurderer deserves exe-

abated following Diaz's suicide while in custody. See Rachel L. Swarns, Man Held in Police Death is Found Hanged in Jail, N.Y. Times, Sept. 6, 1996, at A1; Jan Hoffman, Factions on Death Penalty Issue Gird for Battle, N.Y. Times, Sept. 6, 1996, at B4; see also In re Johnson, 61 Crim. L. Rep. (BNA) 1004 (N.Y. App. Div. 1st Dept, Mar. 20, 1997 (finding Johnson's challenge to Pataki's order non-justiciable).

${ }^{*}$ See Henry M. Hart, Jr., The Aims of the Criminal Law, 23 Law \& Contemp. Probs. 401, 404 (1958) (difference between criminal and civil penalties is that "judgment of community condemnation" accompanies criminal sanction); see also Morrison v. Olson, 487 U.S. at 712-13 (Scalia, J., dissenting) (noting "frightening" prospect of being investigated by prosecutor neither selected by nor subject to control of the President); William T. Pizzi, Understanding Prosecutorial Discretion in the United States: The Limits of Comparative Criminal Procedure as an Instrument of Reform, 54 Ohio St. L.J. 1325, 1339 (1993) ("If someone is to decide which laws will be aggressively enforced, which laws will be enforced occasionally, and which laws will never be enforced, it makes sense that the person who has to answer to the voters will make those determinations.").

"Davis, supra note 69, at 207-08. See Donald G. Gifford, Meaningful Reform of Plea Bargaining: The Control of Prosecutorial Discretion, 1983 U. Ill. L. Rev. 37, 54 (discussing low visibility of plea bargaining decisions).

s See James Eisenstein, Politics and the Legal Process 21-22 (1973) (noting that frequency of uncontested elections for this office "is probably unusually high" compared with those for other offices).

${ }^{8}$ See Jacoby, supra note 74, at 261 (Boulder County, Colorado D.A. "elected [in 1972] on a platform opposing the prosecution of lesser marijuana cases"); Carl Quintanilla, A Prosecutor Wins Battle against Drugs but Loses the War, Wall St. J., Jan. 16, 1997, at A1 (attributing electoral loss of county attorney in western Kansas to 
cution, ${ }^{84}$ or on the loss of a high-profile case, ${ }^{85}$ as well as on an office's overall win-loss record. Individual referenda on the broad range of discretionary choices that every prosecutor makes are unlikely, indeed utterly impossible. ${ }^{86}$

The point is not new. In 1929, Roscoe Pound observed:

Political responsibility was a cleck on the prosecutor in a proper sense in pioneer America, where dockets were small, where the citizens in large and representative numbers attended all trials, where every one knew what the prosecutor did

public rejection of his "tenacious prosecution of [drug] smugglers apprehended in the county").

${ }^{84}$ F. Thomas Schornhorst, Preliminary Screening of Prosecutorial Access to Death Qualified Juries: A Missing Constitutional Link, 62 Ind. L.J. 295, 306 (1987) ("The kinds of murders that excite a community's fervor for the death penalty are, relatively speaking, rare occurrences. An elected prosecutor's choice to initiate a capital case cannot be divorced from the prosecutor's desire for reelection.").

${ }^{85}$ In his fascinating study of one county, Stuart Scheingold noted:

[J]udges and prosecutors ... preserved a significant measure of autonomy for dealing with the overwhelming majority of their cases by giving up much of their autonomy in those prosecutions that were inescapably politicized because of the notoriety of the participants or of the circumstances. But the charges strongly influenced by political calculations were something of a sideshow. In this and other ways, public attention was diverted from the vast bulk of cases that were dealt with according to sheltered routines.

Stuart A. Scheingold, The Politics of Street Crime: Criminal Process and Cultural Obsession 123 (1991).

One need not look far for examples of the role that high-profile cases can play in the election of district attorneys. See Alan Abrahamson, Challenger Concedes D.A. Race to Garcetti, L.A. Times, Nov. 23, 1996, at B3 ("By the narrowest of margins, Garcetti... was reelected to a second term in a race that was widely viewed as a referendum on the failed prosecution of the O.J. Simpson murder case."). The Washington Post also reported that:

Despite his office's record of success in criminal cases, the non-partisan primary campaign [for district attorney] was dominated by criticism that Garcetti's deputies failed to win convictions in a string of high-profile trials, including the Menendez brothers' first murder trial, rapper Snoopy Doggy Dogg's murder trial and, most important of all, the marathon Simpson trial.

William Claiborne, L.A. District Attorney Garcetti Haunted by Case That Won't Go Away, Wash. Post, Apr. 4, 1996, at A3. See also id. ("Garcetti acknowledged that Los Angeles County has a long tradition of high-profile trials affecting political contests ....").

${ }^{86}$ This is not to say that a prosecutor will feel the effects of the political process only at election time. See Abrams, supra note 74, at 1419 (noting prosecutors' formal and informal meetings with a "range of constituents, including organized interests such as victims' rights groups"). The point goes to the generality, or, alternatively, the narrowness of electorate's input. 
and low and why. Political responsibility kept him from domg what he should not. Nowadays, politics are a clieck in an improper sense, hindering him from doing what he slould. ${ }^{87}$

Perhaps electoral or appointive politics ${ }^{88}$ will ensure that the community's preferences will at least be considered on some broad issues of the guns vs. butter variety: Should enforcement of the narcotics laws be favored over the enforcement of the ganıbling laws? And, if narcotics trafficking is to be targeted, how high a priority should be given to street dealers? But the bulk of the discretionary decisions that prosecutors make turn not on such broad matters of policy but on the individual circumstances of putative defendants, alleged victims, and other such case-specific factors. Electoral or appointive politics are, at best, a poor way of holding prosecutors accountable for this myriad of low-visibility enforcement decisions. Even those prosecutors who actively court community participation in decisionmaking ${ }^{89}$ may not hear views on such fine-grained matters. Further, to the extent that views are expressed, the expressions will tend to be from highly interested parties. Neither will any help conie from the courts, which-at least as a formal inatter $^{\text {- }}$-have declined to venture into this executive area, save in the clearest cases of invidious discrimination..$^{11}$

7 Roscoe Pound, Criminal Justice in America 185 (1930). See also Sam Earle Hobbs, Prosecutor's Bias, An Occupational Disease, 2 Ala. L. Rev. 40, 45 (1949) ("Nowadays politics are a check in an improper sense, hindering the prosecutor... from doing what he should" and "developing in him .... a frenetic zeal for 'getting results' in the form of convictions which transcend the bounds of civilized morality." (quoting Pound, supra, at 185)).

$\$$ Electoral politics may be of particular interest to the prosecutor who hopes to turn his position into a springboard for higher electoral office. See Scheingold, supra note 85 , at 130 ; Kahan, supra note 69 , at 486 . The political concerns of the prosecutor seeking advancement, however, presumably will not be very different from those of the prosecutor seeking retention in a contested election.

"In the District of Columbia, for example, the United States Attorney recently established a "community prosecution" program, placing a team of prosecutors in closer contact with one community in the District. See Bill Miller, Prosecutors to Act as Community Advocates; U.S. Attorney Begins Experimental Program, Wash. Post, June 6, 1996, at J1; Sam Skolnik, Working the Streets, Legal Times, Nov. 27, 1995, at 6.

${ }^{\circ}$ See Eisenstein, supra note 60 , at 132 (" [F]ield research suggests that U.S. attorneys modify prosecutive decisions both in response to direct [albeit informal] initiatives of judges and through anticipation of judicial reactions."); id. at 133 ("Just as certain types of cases are not prosecuted due to the cool reception they elicit from 


\section{The Prosecutor's Motivation}

That the community's voice is not directly heard on finegrained matters of prosecutorial priorities, however, does not mean that its preferences will not resound loudly in prosecutors' offices. One need not posit that prosecutors feel any obligation to represent their constituencies. It is enough that they seek to maximize convictions.

It is surely simplistic to say that all prosecutors are primarily interested in maximizing convictions. ${ }^{92}$ Although an impressive conviction rate will undoubtedly enhance personal and group job security, the question remains: Why this job? The motivations of those attracted to a job for which the remuneration can be comparatively low, in a legal market where the opportunities to shirk abound, will be far more complex. Much work remains to be done in exploring the personal ideologies of prosecutors, ${ }^{93}$

judges, so too are others pushed vigorously because of obvious judicial interest in them.").

${ }^{91}$ In United States v. Armstrong, 116 S. Ct. 1480 (1996), the Court noted that a "selective-prosecution claim asks a court to exercise judicial power over a 'special province' of the Executive." Id. at 1486 (quoting Heckler v. Chaney, 470 U.S. 821, 832 (1985)). The Court also emphasized the onerous burden on any defendant seeking to prove that a decision to prosecute was based on "an unjustifiable standard such as race, religion, or other arbitrary classification." Id. (quoting Oyler v. Boles, 368 U.S. 448, 456 (1962)). See also United States v. Wayte, 470 U.S. 598, 608 (1985) (describing federal courts as "properly hesitant to examine the decision whether to prosecute"); Vorenberg, supra note 69.

${ }^{92}$ Alissa Worden has noted that:

[R]esearch on prosecutors has been handicapped by overly simplified conceptions of prosecutorial motivations, such as the assumption that all prosecutors strive to maximize convictions or to impose maximally harsh sentences, despite the fact that interviews and observation have revealed considerable variation in prosecutors' values and beliefs, incentives and role orientations.

Alissa Pollitz Worden, Policymaking By Prosecutors: The Uses of Discretion in Regulating Plea Bargaining, 73 Judicature 335, 335 (1990).

${ }^{93}$ Brian Grosman made a good start in his insightful study of a Canadian Crown Attorney's Office:

The attractions of the prosecutorial office and its satisfactions are seldom restricted to the evident training opportunities, the relative freedom from supervisory control, or to the benefits derived from the variety of daily activities. The nature of the prosecuting institution itself, combining as it does the considerable power components of the police and prosecuting establishments and the authority of public morality and social control, draws to it those who desire to act from a position of power. 
the influence of long-term economic self-interest, ${ }^{94}$ and the psychological aspects of prosecutors' self-selection.

Whatever prosecutors' private motivations are, however, the need to maximize convictions will be an inescapable environmental constraint. This imperative is, in part, a function of the political process. Those elections that are contested are often fought on an incumbent's win-loss record, ${ }^{95}$ and an incumbent's concerns in this regard will be felt by his subordinates. ${ }^{96}$ But the need to maximize convictions arises from other sources as well. Even in Umited States Attorneys' offices, where the chief can be removed only by the President and her assistants are substantially imsulated from political pressure, ${ }^{97}$ "[t] he need to win cases constitutes the strongest incentive in the work environment of assistants." 98 James Eisenstein found:

Brian A. Grosman, The Prosecutor: An Inquiry into the Exercise of Discretion 64 (1969).

* See, e.g., Eisenstein, supra note 60, at 174 (finding that "the overwhelming majority of [assistant U.S. attorneys] seek the position not for the inherent rewards of public service, but for the boost it can give their subsequent careers"); Richard S. Frase, Comparative Criminal Justice as a Guide to American Law Reform: How Do the French Do It, How Can We Find Out, and Why Should We Care?, 78 Cal. L. Rev. 539, 563 (1990) (contrasting American system with the French system of "career" prosecutors); Weaver, supra note 69, at 162 (Antitrust Division and the private bar "constitute two parts of a single job market").

${ }^{95}$ See Gordon Van Kessel, Adversary Excesses in the American Criminal Trial 67 Notre Dame L. Rev. 403, 442 n.164 (1992) ("Elected state prosecutors often face bitter contests in which their win-loss record becomes a campaign issue."); Scheingold, supra note 85 , at 126 (noting that a "high conviction rate" is "frequently presented by prosecutors as evidence of effective crime control"); id. at 136 (example of one such campaign claim); Worden, supra note 92, at 337 ("Conviction rates constitute simplistic but easily advertised indicators of success, since they appear to measure prosecutors' ability to win cases.").

* A 1975 study of a number of prosecutors' offices found four different models of prosecutorial policy: "legal sufficiency" (charges brought whenever elements of crime present); "system efficiency" (aiming for speedy and early disposition of cases by any means possible); "defendant rehabilitation"; and "trial sufficiency." Leonard $\mathrm{R}$. Mellon, Joan E. Jacoby \& Marion A. Brewer, The Prosecutor Constrained by His Environment: A New Look at Discretionary Justice in the United States, 72 J. Crim. L. \& Criminology 52, 59 (1981). The study also found that line prosecutors in the offices studied "generally tend[ed] to follow their policy leaders." Id. at 79 . The degree to which line prosecutors seek to maximize convictions will be influenced by which of these models is selected by their superiors (to the degree these models are still prevalent). See also Jacoby, supra note 74, at 201-05.

${ }^{7}$ See Eisenstein, supra note 60, at 97.

$\$ 8$ Id. at 152. 
[T] he standing of an assistant among his peers depends in part on his conviction record. His record also determines his reputation among the judges and members of the private bar, and this reputation in turn affects the job opportunities available when he leaves. Furthermore, U.S. attorneys utilize conviction rates to assess the work of their assistants. Despite the problems with conviction rates, they provide U.S. attorneys with a means of comparing the performance of their assistants, judging the efficiency of manpower allocations, and demonstrating to "a rather ill-defined public constituency" demanding convictions that they are fulfilling their obligation. A U.S. attorney's standing with the local judges depends upon his ability to facilitate movement of the docket, which in the criminal area requires maintaining a high guilty plea rate. Without a high conviction rate, the guilty plea system is jeopardized. ${ }^{99}$

The prosecutor's interest can also be described as one in "non-defeat."

In the county studied, the prosecutor's office cared less about winning than about not losing. The norm is so intrinsic to the rationale of the prosecutor's office that one does not often liear it articulated. Nevertheless it is very powerful. It cannot be attributed to such a simple and obvious fact as the periodic requirement of reelection. Indeed, reelection seemed to be taken for granted, and an observer would be hard put to relate prose-

"Id. at 152-53. See Richard S. Frase, The Decision to File Federal Criminal Charges: A Quantitative Study of Prosecutorial Discretion, 47 U. Chi. L. Rev. 246, 310-13 (1980) (discussing data showing that factors other than convictability account for differential prosecution rates); John Kaplan, The Prosecutorial Discretion-A Comment, 60 Nw. U. L. Rev. 174, 180-81 (1965); Sidney I. Lezak \& Maureen Leonard, The Prosecutor's Discretion: Out of the Closet, Not Out of Control, in Carl F. Pinkele \& William C. Louthan, Discretion, Justice, and Democracy: A Public Policy Perspective 44, 46 (1985) ("Winning is important not only for the ego satisfaction and enhancement of reputations that victory brings, but also because a record of winning makes it easier to dispose of cases by favorable plea bargains in the future."); Robert L. Rabin, Agency Criminal Referrals in the Federal System: An Empirical Study of Prosecutorial Discretion, 24 Stan. L. Rev. 1036, 1045 (1972) (finding that "convictions are the central performance standard" in U.S. Attorney's offices); Weaver, supra note 69, at 144-45 (congressional hearings relating to oversight of Antitrust Division focus on "cases brought, proportion of cases won, severity of sentences, and amounts of fines and damages"); cf. Miller, supra note 68 , at $22,342-43$ (conviction maximization hypothesis "must remain uncertain," not supported by field studies).

${ }^{100}$ Jerome H. Skolnick, Social Control in the Adversary System, 11 J. Conflict Resol. 52, 57 (1967). 
cutorial decisions directly to electoral requirements. Not only does the prosecutor desire to maintain a respectable record, but more than that, he seeks to maintain, msofar as possible, a reputation for utter credibility.... ${ }^{10}$

"Credibility," Skolnick explains, "leads to victory, victory to ... quasi-magisterial status, and quasi-magisterial status to enhanced credibility, all of which eases the task of the prosecutor."102

\section{The Community's Voice}

Undoubtedly, prosecutors' drive to maximize convictions can lead to, and has led to, some of their worst excesses-the tactics of those for whom winning is everything. ${ }^{103}$ Within the framework of a single case, this impulse is in tension with the "Minister of Justice" ideal. Prosecutors, however, do not operate within the framework of a single case. Indeed, in a world of plea bargaining, case selection is at least as important a part of a prosecutor's job as case disposition. And in this broader perspective, the prosecutorial drive to maximize convictions emerges as potentially the most effective mechanism for ensuring that prosecutors consider community enforcement priorities over the entire range of possible cases. This, in turn, becomes the principal means through which the community gains a voice in the day-to-day decisions about who gets charged with what.

Thomas Jefferson once avowed:

Were I called upon to decide whether the people had best be omitted in the legislative or judiciary department, I would say it is better to leave them out of the legislative. The execution of the laws is more important than the making of them. ${ }^{104}$

101 Id.

102 Id. at 58.

${ }^{103}$ See George T. Felkenes, The Prosecutor: A Look At Reality, 7 Sw. U. L. Rev. 98, 117 (1975) (use of conviction rate as measure of office efficiency stimulates development of "conviction psychology" in prosecutors); Van Kessel, supra note 95, at 447-58; Fred C. Zacharias, Structuring the Ethics of Prosecutorial Trial Practice: Can Prosecutors Do Justice, 44 Vand. L. Rev. 45 (1991).

${ }^{104}$ Letter from Thomas Jefferson to L'Abbe Arnond (July 19, 1789), in 5 The Works of Thomas Jefferson 483, 484 (Paul Leicester Ford ed., 1904). 
This point might be taken (and has been taken) in its narrow sense, as a paean to the power of juries to nullify: Trial by jury allows jurors, acting as representatives of the community, to ensure that a prosecution coniports with sone conmunal sense of justice. When a jury nullifies-i.e., refuses to convict despite the strength of the evidence-the acquittal not only prevents the iniposition of criminal sanctions on the defendant on trial but also "conveys significant information about community attitudes and provides a guidelime for future prosecutorial discretion in the enforcenient of the laws." ${ }^{105}$ In this limited sense, criminal juries give ordinary citizens a voice-albeit solely a veto-in the execution of the laws. ${ }^{106}$

So many explorations of the role that juries can or should play in the enforcement of the law envision a nragic moment of nullification-the moment when a jury stares down the prospect of a fully proven case and self-consciously declines to convict. ${ }^{107}$ But

${ }^{105}$ Alan Scheflin \& Jon Van Dyke, Jury Nullification: The Contours of a Controversy, Law \& Contemp. Probs., Autumn 1980, at 51, 71. Frank Miller has also noted that:

To the extent that guilty persons are not charged because of perceived problems in the sufficiency of the evidence to convince the trier of fact of guilt... [a]lmost invariably the charging pattern is related to a play-back effect of past trials on similar charges under similar circumstances from which prosecutors have derived experience enough to realize that to charge would be a futile gesture....

Miller, supra note 68, at 43. See also Note, Laws That Are Made To Be Broken: Adjusting for Anticipated Noncompliance, 75 Mich. L. Rev. 687, 709 (1977) ("When juries regularly refuse to convict under a particular law, prosecutors are apt to lose incentive to prosecute under that law, and the law becomes ripe for repeal or may, under some circumstances, become void."); Rabin, supra note 99, at 1053 ("[T]he attitudes of judge and jury toward an offense, or a specific violation, are an important determinant of enforcement policy.").

In the jury deliberations featured in Inside the Jury Room, supra note 43, several jurors suggested that an acquittal would send a message to the District Attorney's Office not to bring any more felon-in-possession cases against defendants who posed no risk to the community.

${ }^{106}$ See Vikram David Amar, Jury Service as Political Participation Akin to Voting, 80 Cornell L. Rev. 203 (1995).

${ }^{107}$ See, e.g., Akhil Reed Amar, The Bill of Rights as a Constitution, 100 Yale L.J. 1131, 1185-89 (1991); Paul Butler, Racially Based Jury Nullification: Black Power in the Criminal Justice System, 105 Yale L.J. 677 (1995); Andrew D. Leipold, Rethinking Jury Nullification, 82 Va. L. Rev. 253 (1996). 
such moments are probably rare, if they happen at all. ${ }^{108}$ Indeed, the complex of doctrines that so strongly insulates jury acquittals against review is in large part based on the irrebuttable presumption that an alternative explanation for an acquittal can always be found. ${ }^{109}$ As Kalven and Zeisel found in their pioneering study, "the jury does not often consciously and explicitly yield to sentiment in the teeth of the law. Rather it yields to sentiment in the apparent process of resolving doubts as to evidence."110

In their "hiberation hypothesis," Kalven and Zeisel proposed that "sentiment gives direction to the resolution of the evidentiary doubt; the evidentiary doubt provides a favorable condition for a response to the sentiment.'" magic moment of nullification is just an endpoimt on a continuum of iuterplay between proof and "sentiment"-a continuum in which the burden of proof actually faced by prosecutors turns, at least in part, on all those factors giving rise to sentiment. ${ }^{112}$ Kalven and Zeisel identified certain factors that can raise the burden considerably: sympathetic defendants, de minimis crimes, and unpopular laws. ${ }^{1.3}$ Other factors presumably will have the opposite effect: heinous crimes, a defendant perceived as

${ }^{108}$ See Reid Hastie, Introduction, in Inside the Juror, supra note 40, at 29 (finding "little evidence that jurors depart from the factfinding task to follow the dictates of conscience or to apply their sense of fair play when deciding criminal trial verdicts"); Dorfman \& Iijima, supra note 23 , at 893 (noting that a "far more frequent phenomenon" occurs when a "jury nullifies without understanding that it is doing so, through fictions and surrogates").

${ }^{109}$ Explaining why jurors could not be punished for daring to acquit the Quakers William Penn and William Mead, Chief Justice Vaughan reasoned:

A man cannot see by anothers eye, nor hear by anothers ear, no more can a man conclude or infer the thing to be resolv'd by anothers understanding or reasoning; and through the verdict be right the jury give, yet they being not assur'd it is so from their own understanding, are forsworn, at least in foro conscientiae.

Bushell's Case, 1 Vaughan 135, 148; 124 Eng. Rep. 1006, 1013 (C.P. 1670). See Peter Westen, The Three Faces of Double Jeopardy: Reflections on Government Appeals of Criminal Sentences, 78 Mich. L. Rev. 1001, 1012-18 (1980).

${ }^{10}$ Kalven \& Zeisel, supra note 17 , at 165 .

"11 Id.

"12 See Mirjan Damaska, Evidentiary Barriers to Conviction and Two Models of Criminal Procedure: A Comparative Study, 121 U. Pa. L. Rev. 506, 542 (1973) ("[I]t seems psychologically naive to assume that sufficiency of proof requirements do not change in the process of decisionmaking.").

${ }^{113}$ Kalven \& Zeisel, supra note 17, at 193-350. 
posing a future risk to the community, or one deemed unsympathetic for less legitimate reasons. To put the matter in the terms profitably suggested by Richard Lempert: Jurors will be acting to minimize the prospect of personal regret in all cases, and whatever they learn-whether or not legally "relevant"-relating to the personal characteristics of victims and defendants, as well as aspects of criminal activity, will influence their readiness to convict (or acquit) based on any given quantum of evidence. ${ }^{114}$ This does not necessarily mean that the more odious the crime, the more serious the charge, the less protection a defendant can expect from the judge's instructions about reasonable doubt. Jurors' assumptions about penalties may in fact make them less ready to convict for more serious offenses. ${ }^{115}$ But this interplay between burden and sentiment does mean, at least, that where jurors' expectations about penalties are roughly equal, ${ }^{116}$ they

${ }^{134}$ See Lempert, supra note 17, at 1032-37; see also Reid Hastie, Algebraic Models of Juror Decision Processes, in Inside the Juror, supra note 40, at 104 (juror's decisional criterion in which "considerations of the satisfaction or utility of the outcome are paramount").

"1s See Martha A. Myers, Rule Departures and Making Law: Juries and Their Verdicts, 13 Law \& Soc'y Rev. 781, 794 (1979) (empirical study finds juries more likely to acquit if offense serious; may "reflect the use of a higher standard of proof for these crimes"); Norbert Kerr, Stochastic Models of Juror Decision, in Inside the Juror, supra note 40, at 126-27 ("Attorneys, judges, and legislators believe that as penalty increases, all other things being equal, jurors will become less likely to convict." But "[w]hen we turn to the experimental research literature, we find less consistent support for the hypothesis of penalty effects on verdicts."). Compare Jonathan L. Freedman et al., Severity of Penalty, Seriousness of the Charge, and Mock Jurors' Verdicts, 18 Law \& Hum. Behav. 189 (1994) (finding no evidence from mock jury studies that jurors are less likely to convict when offense more serious or penalty more severe), and Jonathan L. Freedman, Penalties and Verdicts: Keeping the Record Straight, 18 Law \& Hum. Behav. 699 (1994) (attempting to disprove experimental literature's claims that extreme penalties reduce conviction rates), with Martin F. Kaplan \& Sharon Krupa, Severe Penalties under the Control of Others Can Reduce Guilt Verdicts, 10 Law \& Psych. Rev. 1 (1986) (pointing to empirical evidence that suggests penalty severity can have an effect on conviction decisions), and Martin F. Kaplan, Setting the Record Straight (Again) on Severity of Penalty: A Comment on Freedman et al., 18 Law \& Hum. Behav. 697 (1994) (criticizing Freedman and others as premature in their conclusions about the effect of penalty severity on jurors).

${ }^{116}$ Although trial judges will generally take pains to prevent jurors from speculating as to the possible sentence in a criminal case, see 1 Edward E. Devitt et al., Federal Jury Practice and Instructions $\S 20.01$, at 822 (4th ed. 1992) (pattern instruction); Kristen K. Sauer, Note, Informed Conviction: Instructing the Jury about Mandatory Sentencing Consequences, 95 Colum. L. Rev. 1232, 1242 n. 59 (1995) (citing cases), it 
will convict more readily in cases where they perceive a defendant to pose a greater threat to society and less readily when they do not.17

Once one recognizes the full extent to which jurors' responses to defendant, victim, and crime characteristics can influence the likelihood of conviction, Jefferson's point takes on a far more sweeping meaning. ${ }^{118}$ The prosecutor who wants to maximize her conviction rate, by plea or by trial, must make all her decisions in the shadow of projected jury responses. ${ }^{119}$ By doing so, she gives the community a voice across the whole range of her case selection decisions. It is not necessarily the strongest of voices, since considerations of evidentiary strength or numerous other factors may predominate in the calculus. ${ }^{120}$ Nor is it the clearest of voices, given the inscrutability of general verdicts.

is fair to assume that "most jurors have at least a general idea of the penalties facing the accused." Freedman et al., Severity of Penalty, supra note 115, at 201.

${ }^{177} \mathrm{Kerr}$, supra note 115 , at $128-29$ ("[A]ny factor which increases the [perceived] cost of the juridic Type II error, acquitting a guilty defendant, should lower conviction criteria and raise conviction rates."). Anecdotal evidence certainty supports this hypothesis. Any prosecutor can tell you that, all other things being equal, it is a whole lot harder to get a conviction in a two-vial crack case than in a 60-kilo cocaine case, much harder to convict a public official for taking a $\$ 500$ bribe than for a $\$ 1$ million payoff.

The documentary Inside the Jury Room, supra note 43, provides an excellent example of the interplay between sentiment and proof in a felon-in-possession case. Faced with an extremely sympathetic defendant, several jurors were quite creative in constructing theories about why someone whose lawyer had conceded possession in his opening really had not possessed a gun at all.

${ }^{118}$ As de Tocqueville put it: "The jury system as understood in America seems to me as direct and extreme a consequence of the ... sovereignty of the people as universal suffrage. They are both equally powerful means of making the majority prevail ...." Alexis de Tocqueville, Democracy in America 273 (Jacob P. Mayer ed., 1969).

${ }^{119}$ See Milton Huemann, Plea Bargaining (1978); Robert E. Scott \& William J. Stuntz, Plea Bargaining as Contract, 101 Yale L.J. 1909 (1992).

To the extent that a prosecutor is dubious about her chances of success before a jury but counts on defense counsel's inability to appreciate these odds, she may persevere with charges in hopes of obtaining a guilty plea. See Leipold, supra note 107 , at 301 . In the absence of information about who counsel will be, or of a universe of potential counsel that reliably can be presumed ineffective, such risk taking will presumably be rare. See Alan Schwartz \& Louis L. Wilde, Intervening in Markets on the Basis of Imperfect Information: A Legal and Economic Analysis, $127 \mathrm{U}$. Pa. L. Rev. 630, 640-51 (1979).

${ }^{120}$ The strength of the voice may also be reduced by a sentencing scheme that inflicts so great a penalty on defendants convicted after trial that only those highly confident of acquittal will take the risk. 
And it is not a voice finely calibrated to differentiate among all cases. Yet through it, the community has a far greater say in how prosecutors deploy their resources than it has through any more direct mechanism of political accountability. ${ }^{121}$

Any suggestion that verdicts represent some general community voice is open to the challenge that juries simply do not possess this representative quality - a challenge that those questioming the legitimacy of nullification articulate most clearly. ${ }^{12}$ In our fragmented society, we can no longer speak of a single community, the argument goes. ${ }^{123}$ Even if we could, the randomness of petit jury selection does not ensure that this community will be recreated for a trial. ${ }^{124}$ Even were that possible, any claim to representation in the jury pool would be confounded by peremptory strikes and other tactics that parties use to rig jury membership.

This critique casts serious doubt on any claim that, viewed ex post, a particular jury verdict represents some general communal judgment. Ex ante, however, the prosecutor making resource deployment decisions with an eye to maximizing convic-

${ }^{121}$ Whether projected verdicts affect prosecutorial decisionmaking consciously or through reinforcement will doubtless vary from case to case, but the effects can be identical. See Jon Elster, Nuts and Bolts for the Social Sciences 82-83 (1989) (distinguishing rational choice from reinforcement).

For all this, however, the Department of Justice's "Principles of Federal Prosecution" doggedly declare: "The potential that-despite the law and the facts that create a sound, prosecutable case-the fact-finder is likely to acquit the defendant because of the unpopularity of some factor involved in the prosecution or because of the overwhelming popularity of the defendant or his/her cause, is not a factor prohibiting prosecution." United States Attorneys' Manual § 9-27.220, cmt. (1993).

${ }^{12}$ See Leipold, supra note 107, at 299-301; Phillip B. Scott, Jury Nullification: An Historical Perspective on a Modern Debate, 91 W. Va. L. Rev. 389, 422 (1989); Jeffrey Abramson, We, the Jury 89 (1994); Steven M. Warshawsky, Note, Opposing Jury Nullification: Law, Policy, and Prosecutorial Strategy, 85 Geo. L.J. 191, 218-19 (1996). But see Dorfman \& Iijima, supra note 23, at 901 (giving juries an explicit authorization to nullify "would inject more democracy into the justice system, rather than usurp its influence, and would serve as a direct reminder from the bench that one of the purposes of the jury is to reflect community values").

"23 See William E. Nelson, Americanization of the Common Law: The Impact of Legal Change on Massachusetts Society, 1760-1830, at 165-66, 174 (1975).

${ }^{124}$ But see Abrams, supra note 74, at 1432 n.120 ("[T] in its goal of producing a 'cross-section' of the community-comes closer [than elections] to the understanding that a community's views are not unitary but multiple and conflicting."). 
tions, unaware of future petit jury composition, will consider the predicted reaction of a far more representative jury than will ever actually be impaneled. This will not be true where a group is systematically excluded from juries. Even defenders of jury nullification are forced to admit ${ }^{125}$ that the ugly side of the relationship between juries, verdicts, and prosecutorial discretion is a history of racist justice. ${ }^{126}$ But where a jury pool is indeed representative, the conviction-maximizing prosecutor will, in her discretionary decisions, pay as inuch heed to minority viewpoints under the present scheine as she would im a system of representative racial quotas on trial juries. ${ }^{127}$ Frown this ex ante perspective, the mere possibility of a jury trial can bring an often overlooked degree of accountability into our system of essentially administrative justice.

\section{B. Verdicts and Evidentiary Rules}

There is a Newtonian neatness to the model I have just outlined. It even has some normative appeal-not as a self-contained vision of justice, since one can hardly justify a majoritar-

${ }^{125}$ See, e.g., Butler, supra note 107, at 680 n.11, 705; Dorfman \& Iijima, supra note 23 , at 903.

${ }^{126}$ See Abramson, supra note 122, at 61-62; Albert W. Alschuler \& Andrew G. Deiss, A Brief History of the Criminal Jury in the United States, 61 U. Chi. L. Rev. 867, 890-91 (1994); Gary J. Simson, Jury Nullification in the American System: A Skeptical View, 54 Tex. L. Rev. 488, 514 (1976) (“[B]y activating local biases, jury nullification may at times in effect immunize criminal acts visited upon members of society's 'discrete and insular minorities' ....").

I do not mean to suggest that prosecutors who charged blacks with serious crimes under circumstances in which they would have brought lesser charges (or no charges at all) against whites did so simply in response to their expectations of jury sentiments. But prosecutorial and jury biases certainly can reinforce one another, with racial considerations entering into assessments of "evidentiary strength." See Martha A. Myers \& John Hagan, Private and Public Trouble: Prosecutors and the Allocation of Court Resources, 26 Soc. Probs. 439 (1979).

${ }^{127}$ For discussions of the merits of racial quotas for petit juries, see, e.g., Albert W. Alschuler, Racial Quotas and the Jury, 44 Duke L.J. 704 (1995); Sheri Lynn Johnson, Black Innocence and the White Jury, 83 Mich. L. Rev. 1611, 1698-99 (1985); Andrew G. Deiss, Negotiating Justice: The Criminal Trial Jury in a Pluralist America, 3 U. Chi. L. Sch. Roundtable 323, 353-54 (1996); see also Nancy J. King, Racial Jurymandering: Cancer or Cure? A Contemporary Review of Affirmative Action in Jury Selection, 68 N.Y.U. L. Rev. 707, 767-75 (1993) (disapproving of racial quotas in the jurybox, but favoring some front-end race-conscious selection process). 
ian system that makes the government's burden of proof turn on a defendant's jury appeal or his victim's lack thereof. ${ }^{128}$ But the model highlights how the community's voice can be heard even in a system where prosecutorial discretion is virtually unchallengeable and most cases never make it to trial.

The tension between justice and accountability is heightened once one takes a step from potentiality toward reality and introduces evidentiary doctrine into the mix. Critical to the notion of jury verdicts as guides to the kinds of cases the public wants pursued is the assumption that jurors know all the facts that they would find salient in a case. Yet our system of exclusionary rules of evidence frequently ensures that this will not happen. ${ }^{129}$ This point is most dramatically illustrated when a trial judge bars a defendant from presenting evidence and arguments that explicitly court nullification. ${ }^{130}$ The phenomenon has far broader dimensions as well: Every evidentiary rule that-for fear of jury misvaluation, "inflammation," or nullification-prevents the jury from learning something about a criminal defendant, his victim, or his crime tends to rob verdicts of the power to commumicate the community's actual prosecutorial priorities. ${ }^{131}$

${ }^{128}$ See Alan W. Scheflin, Jury Nullification: The Right to Say No, 45 S. Cal. L. Rev. 168,215 (1972) ("For the jury to convict against the law as it has been announced to them is tantamount to finding the defendant guilty of a crime when in fact his act may not have been criminal but for the retroactive application of a new principle.").

${ }^{129}$ See Leipold, supra note 107, at 303 (defenders of nullification assume that jurors have enough information to make reasoned decision).

${ }^{130}$ See, e.g., United States v. Montgomery, 772 F.2d 733, 736-38 (11th Cir. 1985) (trespassers at nuclear facility barred from explaining implications of nuclear power and nuclear weapons); see also Douglas L. Colbert, The Motion In Limine in Politically Sensitive Cases: Silencing the Defendant at Trial, 39 Stan. L. Rev. 1271, 132227 (1987) (condemning in limine rulings that precluded defendants from raising political defenses that would lead jurors to judge the law as well as the facts in politically sensitive cases); Chaya Weinberg-Brodt, Note, Jury Nullification and Jury Control Procedures, 65 N.Y.U. L. Rev. 825, 857-65 (1990) (giving other examples); Jack B. Weinstein, Considering Jury "Nullification": When May and Should a Jury Reject the Law to Do Justice, 30 Am. Crim. L. Rev. 239, 250 (1993) ("Limiting defense evidence on the grounds that it is irrelevant to a particular legal theory and may therefore prompt nullification is a dubious route."); Warshawsky, supra note 122 , at 228-31 (highlighting a prosecutor's need to be aware of the potential for jury nullification).

${ }^{131}$ In jurisdictions where there is jury sentencing across a broad range of crimesnot merely in capital cases-sentences can take the place of verdicts in this regard. See Markus Dirk Dubber, American Plea Bargains, German Lay Judges, and the 
This is not to say that every exclusionary rule threatens prosecutorial accountability. Particularly gruesome or gory pictures are often kept from juries in murder trials, for fear that they will "arouse the passions and prejudices of the jury."132 Yet it is far from clear that the public would attach inuch importance to these pictures in allocating prosecutorial resources. ${ }^{133} \mathrm{~A}$ bloody murder scene 1might indicate a particular depravity on the part of the murderer, or the extraordinary brutality of the crime, but not necessarily so. In any event, even if the community did respond to the aesthetics of a murder scene-or to the luridness of tabloid coverage, which in turn reflected the aesthetics of the scene-this would be an instance (not necessarily unique) where some insulation of prosecutors from popular sentiments would be acceptable to all. ${ }^{134}$

Where a community response does bespeak at least an arguably well-considered reaction to social harms, however, the costs of an evidentiary doctrine that prevents jury verdicts fron1 reflecting such a response are more troubling. Evidentiary doctrine, for instance, quite correctly fears that a jury will be quicker to convict, or will at least have fewer regrets about convicting, when it learns of a defendant's prior criminal record. ${ }^{135}$ But such reactions find their roots in a sensible belief that recidivists pose a greater danger to the community, and, by extension, should be a prosecutorial priority. ${ }^{136}$ A rule, hike that prevailing in nıost jurisdictions, that generally keeps juries from learning about a defendant's prior record thus can operate to make the purely con-

Crisis of Criminal Procedure, 49 Stan. L. Rev. 547, 595 n.272 (1997) (collecting state statutory citations).

${ }_{132}$ Ritchie v. State, 632 P.2d 1244, 1246 (Okla. Crim. 1981). See also State v. Chapple, 660 P.2d 1208, 1215-17 (Ariz. 1983); State v. Wilson, 310 S.E.2d 486, 487-88 (W. Va. 1983).

${ }^{133}$ Where homicides are concerned, the issue is generally more the degree of prosecutorial effort than whether or not charges will be brought at all.

${ }^{134}$ See Abrams, supra note 74, at 1423 ("[T] oo much emphasis on the vicissitudes of community opinion as compared with the more enduring interests thought to be embodied in criminal law, may detract from the legitimacy of the prosecutor's efforts.").

${ }^{135}$ See supra notes 16-18 and accompanying text.

${ }^{136}$ See Brian Forst \& Kathleen B. Brosi, A Theoretical and Empirical Analysis of the Prosecutor, 6 J. Legal Stud. 177, 179 (1977) (prosecutors likely to reduce overall crime by focusing on recidivists). 
viction-minded prosecutor more concerned with offense seriousness and evidentiary strength than with criminal history. ${ }^{137}$

Ironically, in the one setting where we most desire to erase the differences between cases, in order to foster a disjunction between popular sentiment and prosecutorial priorities, we cannot. If "minority defendants-because of their own race or the race of their victim, [do indeed] receive disproportionately harsher treatment at each stage of the prosecutorial decisionmaking process, ${ }^{, 138}$ the pattern might simply indicate conscious or unconscious racism on the part of the prosecutorial decisionmakers. Yet it could also reflect, or be reinforced by, projected jury responses in such cases. Even a prosecutor harboring no such personal biases will perpetuate the pattern to the extent that she endeavors to maximize convictions and perceives jurors as more likely to convict minority defendants generally,

${ }^{137}$ Id. at $190-91$ (empirical study of 1973 felony arrests in District of Columbia cannot find correlation between defendants' criminal records and the extent of prosecutorial attention to a case; such attention far more sensitive to offense seriousness and strength of evidence). During the period of this study, as now, a defendant's prior convictions were generally not admissible, except to impeach his testimony or prove motive, intent, etc., subject to a balancing test. See Drew v. United States, 331 F.2d 85, 89-90 (D.C. Cir. 1964). The trend toward establishing special units for prosecuting repeat offenders, see Marcia Chaiken \& Jan Chaiken, Redefining the Career Criminal: Priority Prosecution of High-Rate Dangerous Offenders (N.I.J. 1990), may well counterbalance what otherwise would be an insufficient focus on this group. Increased sentences for recidivists would have a similar effect, to the extent that prosecutors maximized sentence-years.

${ }_{138}$ Developments In the Law, Race and the Criminal Process, 101 Harv. L. Rev. 1472,1525 (1988). For a discussion of some of the empirical evidence suggesting such a pattern, see id. at 1525-32; William Bowers et al., Legal Homicide: Death as Punishment in America, 1864-1982, at 67-103 (1980); Randall L. Kennedy, McCleskey v. Kemp: Race, Capital Punishment, and the Supreme Court, 101 Harv. L. Rev. 1388 (1988); Gary D. LaFree, The Effect of Sexual Stratification by Race on Official Reactions to Rape, 45 Am. Soc. Rev. 842, 852-53 (1980); Michael L. Radelet \& Glenn L. Pierce, Race and Prosecutorial Discretion in Homicide Cases, 19 Law \& Soc'y Rev. 587 (1985); Cassia Spohn et al., The Impact of Ethnicity and Gender of Defendants on the Decision to Reject or Dismiss Felony Charges, 25 Criminology 175 (1987); see also Robert J. Sampson \& Janet L. Lauritsen, Racial and Ethnic Disparities in Crime and Criminal Justice in the United States, in 21 Ethnicity, Crime, and Immigration: Comparative and Cross-National Perspectives 311 (Michael Tonry ed., 1997) (reviewing empirical literature and finding no clear pattern of discriminatory enforcement). 
or those with non-minority victims. ${ }^{139}$ Regrettably, information about the race of a defendant or victim is not amendable to manipulation through exclusionary rules of evidence.

Nothing here need be taken as an argument for doing away with, or even relaxing, evidentiary rules like those restricting the introduction of prior convictions. ${ }^{140}$ Although reasonable nuinds might differ, the fairness and fact-finding accuracy values that those rules proniote far outweigh (to me, at least) the interests of prosecutorial accountabihty served by exposing juries to this information. Whether viewed as a "truth-seeking process" or a "drama" from which the public "assimilates behavioral messages," 141 the primary purpose of a criminal trial must be to ascertaim the blameworthiness of the defendant for the charged offense, not to niake some general assessment of his moral deserts or threat to the community. ${ }^{142}$ Nonetheless, we should recognize the potential costs of these and other exclusionary evidentiary doctrines that rob verdicts of the power to communicate the community's prosecutorial preferences, and leave prosecutors freer to exercise virtually unaccountable discretion. These costs are even more troubling to the extent that jurors, deprived of accurate information about, say, a defendant's or victim's background, speculate on such niatters based on stereotypes.

${ }^{139}$ Empirical studies continue to suggest the existence of such bias among juries. See Douglas L. Colbert, Challenging the Challenge: Thirteenth Amendment as a Prohibition Against the Racial Use of Peremptory Challenges, 76 Cornell L. Rev. 1, 110-15 (1990) (reviewing empirical evidence suggesting that all-white juries are more prone to convict black defendants than to convict white defendants). But see Sampson \& Lauritsen, supra note 138, at 346 (finding "no consistent evidence that minorities are disadvantaged at the stage of criminal conviction").

${ }^{140}$ Those who would radically change these long-accepted limitations do not need my help. See Office of Legal Policy, Report to the Attorney General on the Admission of Criminal Histories at Trial, 22 U. Mich. J.L. Reform 707 (1989) (arguing against any such restrictions); see also Fed. R. Evid. 413-415 (relaxing restrictions in sex offense and child abuse cases).

${ }^{141}$ Charles Nesson, The Evidence or the Event? On Judicial Proof and the Acceptability of Verdicts, 98 Harv. L. Rev. 1357, 1360 (1985).

${ }^{142}$ The same rationale also counsels against relaxing rules restricting a defendant's ability to show that he has been a good person in the past. See Fed. R. Evid. 404-405 (criminal defendant restricted to calling opinion or reputation witnesses to show a "pertinent" character trait; evidence of specific past good deeds barred). 


\section{THE RULE IN OLD CHIEF AND PROSECUTORIAL DISCRETION}

Recognizing the tendency of evidentiary rules to drive a wedge between prosecutors and the communities they serve is one thing. Determining whether such rules actually carry these costs is quite another, demanding an inquiry into what makes prosecutors tick. Because it endeavors (however vainly) to preclude verdicts from being influenced by the single factor that most citizens would consider first in judging the appropriateness of a great many $\S 922(\mathrm{~g})(1)$ prosecutions, Old Chief provides an excellent vehicle for asking this question.

When it comes to felon-in-possession cases, the storied discretion of federal prosecutors is at its zenith. A huge number of convicted felons have guns, ${ }^{143}$ and the only real issue of proof at trial is possession..$^{14}$ Moreover, the range of criminal "conduct" is about as broad as that covered by any federal statute: from the convicted murderer carrying a weapon under circumstances suggesting his interest in using it for another murder to our retired lobsterman-felon who wants some protection in his old age (but has failed to procure the requisite waiver). ${ }^{145}$

That federal prosecutors will bring a sizable number of $\S 922(\mathrm{~g})(1)$ cases is virtually certain. One of few areas of com-

${ }^{143}$ Under California's 15-day waiting-period scheme, of 500,000 requests for handgun purchases in 1991, 3,000 rejected purchasers had a prior assault record, and 34 rejected purchasers had a homicide record. Erik Eckholm, Thorny Issue in Gun Control: Curbing Responsible Owners, N.Y. Times, Apr. 3, 1992, at A1, A15. According to an ATF survey of the Brady Bill's effects, of 441,545 applications for handgun purchases from Feb. 1994 to Feb. 1995, 4,365 people were rejected because they had felony records. James B. Jacobs \& Kimberly A. Potter, Keeping Guns Out of the "Wrong" Hands: The Brady Law and the Limits of Regulation, $86 \mathrm{~J}$. Crim. L. \& Criminology 93, 102-03 (1995). Because many felons aware of legal barriers to their ownership of a gun are not likely to file a formal application for purchase and can easily buy guns in the largely unrelated secondary market, see Philip J. Cook, Stephanie Molliconi \& Thomas B. Cole, Regulating Gun Markets, 86 J. Crim. L. \& Criminology 59 (1995), these figures only hint at what must be a rather large number people violating $\$ 922(\mathrm{~g})$. See also James D. Wright \& Peter H. Rossi, Armed and Considered Dangerous: A Survey of Felons and Their Firearms 16 (1986) (in sample of 1,874 incarcerated felons, only $21 \%$ had obtained their most recent handgun from a customary retail outlet; $44 \%$ had obtained it from friends or family, and $26 \%$ from gray and black market sources).

${ }^{144}$ See supra notes 14-15 and accompanying text.

${ }^{145}$ See supra note 10 and accompanying text (setting out waiver procedures). 
mon ground in the often bitter gun control debate is a consensus that the felon-in-possession law should be vigorously enforced. ${ }^{146}$ But on what basis will prosecutors select among the vast universe of potential defendants cases? ${ }^{147}$ Chance will play a sigmificant role. When local police respond to a "man with a gun" call and find that the suspect has a prior felony, they might well hand him over for a quick federal prosecution. ${ }^{148}$ But beyond that, will the Justice Department focus on the armed felons who pose a real danger to the community, or will any armed felon do? Doubtless, many people have decided views on the matter, views that turn on a defendant's background, as revealed by the nature of his prior felony. That was the justifiable assumption of the Court in Old Chief, and all the lower courts that considered the issue presented therein. ${ }^{149}$ But so long as a defendant can preclude juries from learning the nature of his prior felony, the prosecutor interested solely in maximizing convictions ${ }^{150}$ will

${ }^{146}$ See Randy E. Barnett \& Dan B. Kates, Under Fire: The New Consensus on the Second Amendment, 45 Emory L.J. 1139, 1235 (1996) ("[F]or seventy-five years gun groups have insisted on, supported, and actually drafted laws against handgun possession by felons, 'use-a-gun, go-to-jail' laws, ever-harsher penalties for gun possession by felons, gun misuse, and 'three-strike' laws.").

${ }^{347}$ Between October 1, 1994 and April 30, 1996, the Bureau of Alcohol, Tobacco and Firearms referred 5,512 cases for prosecution under $\$ 922(\mathrm{~g})$. This statistic does not separate out cases under $\$ 922(\mathrm{~g})(1)$. Letter from Robert L. Pritchett, Chief, Disclosure Branch, ATF (July 5, 1996) (on file with the Virginia Law Review Association). In fiscal year 1995, United States Attorneys Offices prosecuted 5,327 defendants as part of "Project Triggerlock," see infra notes 159-163 and accompanying text, a figure that does not distinguish between charges under $\S 922(\mathrm{~g})(1)$ and those under other firearms statutes. Sourcebook, supra note 9, at 450 tbl.5.5.

${ }^{143}$ See, e.g., United States v. Lewis, 40 F.3d 1325, 1330 (1st Cir. 1994); United States v. Gilliam, 994 F.2d 97, 98-99 (2d Cir.), cert. denied, 510 U.S. 927 (1993). The head of the Justice Department's Criminal Division noted that:

[T] he most common way that we come across a $922(\mathrm{~g})$ violation is when the person has committed another crime. It is difficult for law enforcement to learn about and be able to prosecute a $922(\mathrm{~g})$ without their having committed another crime because it is very difficult to find them in possession ....

Prosecution of Federal Gun Crimes: Hearing Before the Subcomm. on Crime and Criminal Justice of the House Judiciary Comm., 103d Cong. 49 (1994) (hereinafter Prosecution of Federal Gun Crimes).

149 See supra note 3.

${ }^{130}$ See, e.g., Standen, supra note 70, at $1496 \mathrm{n} .83$ ("In most cases ... the prosecutor's alleged immediate concern is with maximizing the value of his services, usually expressed in terms of wins and losses, both to himself and to his employers, and he will examine the desirability of offering particular plea bargains from this rather 
have no basis for distinguishing among cases. At least that will be true if jurors do not speculate on the basis of stereotypes. If they do, and if the prosecutor presumes they do, the result will be worse because even the racially blind conviction-maximizing prosecutor will find himself disproportionately using $\S 922(\mathrm{~g})(1)$ against young black men, exacerbating one of the worst tendencies of our criminal justice system. ${ }^{151}$ The most unfair aspects of this scenario would be cured if Old Chief were applied asymmetrically, giving defendants who fear stereotyping the option of communicating their actual criminal records to juries. However, not even this reading of Old Chief would eliminate its adverse distributional effects. While all defendants with "serious" felonies would volunteer stipulations, only those who did not fit juror stereotypes of dangerousness would appreciably reduce their chances of conviction though this tactic.

Even if we sharpened our model to assume that prosecutors seek to maximize convictions weighted by sentence, ${ }^{152}$ as opposed to just number of convictions, the potential problem remains. Congress failed to structure $\S 922(\mathrm{~g})(1)$ 's penalties to favor prosecution of felons with the most serious criminal convictions, ${ }^{153}$ and it has established a sentencing guidelines system that

narrow perspective."); Stephen J. Schulhofer, Criminal Justice Discretion as a Regulatory System, 17 J. Legal. Stud. 43, 50-53 (1988).

${ }^{151}$ See Jerome G. Miller, Search and Destroy: African-American Males in the Criminal Justice System (1996); Michael Tonry, Malign Neglect: Race, Crime, and Punishment in America (1995); Joseph F. Sheley, Structural Influences on the Problem of Race, Crime, and Criminal Justice Discrimination, 67 Tul. L. Rev. 2273 (1993). But see Randall Kennedy, The State, Criminal Law, and Racial Discrimination: A Comment, 107 Harv. L. Rev. 1255, 1255-1260 (1994) (noting "overheated allegations of racism" and arguing that main problem confronting black communities is not excessive policing and invidious punishment but failure of state to deploy law enforcement resources evenhandedly); cf. Sampson \& Lauritsen, supra note 138, at 362-63 (reporting that the majority of persons in state and federal prisons are black, and that the incarceration rate of black males is currently seven times the rate for white males, and noting that "[w]ith such enormous disproportionality in sanctioning, it should be of little comfort that most of the disparity is a result of differential involvement in nondrug criminal offending").

${ }_{152}$ See William Landes, An Economic Analysis of the Courts, 14 J.L. \& Econ. 61, 63 (1971); Easterbrook, supra note 62, at 295-96.

${ }^{153}$ Congress could have retained the current form of $\S 922(\mathrm{~g})(1)$, but graded $\$ 922(\mathrm{~g})(1)$ offenses according to the nature of a defendant's prior felony. Analogy might be made to the narcotics distribution statutes, in which drug quantity is not an element of the offense, see United States v. Campuzano, 905 F.2d 677, 679 (2d Cir.), cert. denied, 498 U.S. 947 (1990); United States v. Brown, 887 F.2d 537, 540 (5th Cir. 
substantially limits the ability of defense counsel to extract sentencing discounts from prosecutors for sympathetic defendants. ${ }^{154}$ Indeed, even if the rule in Old Chief were applied asymmetrically, to allow defendants with relatively innocuous prior felonies to communicate that fact to juries, its benefit to them would frequently be limited to the increased probability of acquittal at trial-a benefit that might be outweighed by the loss of the discount generally given under the Federal Sentencing Guidelines to defendants who plead guilty. ${ }^{155}$

The doctrinal areas vary-crime definition, evidentiary rules, sentencing schemes-but one constant emerges: At every point where invisible-hand mechanisms might have been used to ensure prosecutorial accountability or otherwise align prosecutorial choices with community preferences in low-visibility deci-

1989), but is taken into account both in mandatory minimums, 21 U.S.C. $\$ 841$, and in the Federal Sentencing Guidelines, U.S.S.G. § 2D1.1 (1996). See H.R. Rep. No. 99845 , pt.1, at 11 (1986) (creation of five- and ten-year mandatory minimum drug sentences would create incentives for Department of Justice to focus on the most serious drug traffickers). The Sentencing Guidelines are similarly neutral, since the base offense level will be the same for most $\S 922(\mathrm{~g})(1)$ violations, and criminal history points generally do not turn on the nature of a defendant's prior record. U.S.S.G. § 4A1.1 (1996). Congress has graded $\$ 922(\mathrm{~g})(1)$ only in extreme cases. See $\$ 924(\mathrm{e})(1)$ (15-year mandatory minimum for $\$ 922(\mathrm{~g})(1)$ defendant with three previous convictions for "a violent felony or serious drug offense, or both").

156 The precise degree to which the Federal Sentencing Guidelines have limited prosecutorial fiexibility in this regard is a matter of controversy. Compare Stephen J. Schulhofer, Assessing the Federal Sentencing Process: The Problem is Uniformity, Not Disparity, 29 Am. Crim. L. Rev. 833, 845 (1992) (estimating that Guidelines manipulation occurs in "twenty to thirty-five percent" of all guilty plea cases), llene H. Nagel \& Stephen J. Schulhofer, A Tale of Three Cities: An Empirical Study of Charging and Bargaining Practices under the Federal Sentencing Guidelines, 66 S. Cal. L. Rev. 501, 547-49 (1992) (discussing different types of plea bargaining), and John Gleeson, Sentencing Bargaining Under the Guidelines, 8 Fed. Sentencing Rep. 314, 317 (1996) (survey conducted by Probation Officers Advisory Group finds that prosecutors "manipulate" facts to "protect" plea agreements), with Frank O. Bowman III, The Quality of Mercy Must Be Restrained, and Other Lessons in Learning to Love the Federal Sentencing Guidelines, 1996 Wis. L. Rev. 679, 728-30 (taking issue with Schulhofer's estimate). That the Guidelines substantially ended the ability of parties and/or judges to tailor sentences to a defendant's individual circumstances is not in dispute.

1ss See U.S.S.G. § 3E1.1 (two-level adjustment for "acceptance of responsibility"); U.S. Sentencing Comm'n, The Federal Sentencing Guidelines: A Report on the Operation of the Guidelines System and Short-Term Impacts on Disparity in Sentencing, Use of Incarceration, and Prosecutorial Discretion and Plea Bargaining 77-81 (1991) (defendants who plead guilty likely to receive higher sentences under Guidelines). 
sionmaking, Congress or the courts have, for various reasons, chosen not to use them. This tendency, not at all unique to the $\S 922(\mathrm{~g})(1)$ context, presents two fundamental questions. The first is whether, in the absence of such formal mechanisms, there is a systematic disjunction between prosecutorial and community priorities. If there is, reconsideration of these choices might be appropriate. The answers to this question are bound to be impressionistic, even anecdotal. Yet there is reason to believe that federal prosecutors $d o$ try to distinguish between the "hardened criminal," whose access to a gun threatens grave harms, and the retired lobsterman. ${ }^{156}$ Indeed, in a recent congressional hearing, the head of the Criminal Division pointedly assertedcontrary to one congressman's suggestion-that the prosecution of every $\S 922(\mathrm{~g})(1)$ brought to the Justice Department's attention would simply not be "good law enforcement policy."157 And studies of local and federal offices regularly suggest a decent degree of congruence between prosecutorial priorities and community preferences, or at least an effort to achieve such congruence. ${ }^{150}$

The second question is more interesting, and even harder. If there is no such disjunction, why isn't there one? The insights

${ }^{156}$ In his study of "matters" received by the U.S. Attorney's Office for the Northern District of Illinois in 1973-74, Richard Frase found that the prosecution rate for weapons and explosives offenses was $24 \%$. Frase, supra note 99 , at 258 . In $47 \%$ of the cases declined, one reason that the screening prosecutor gave for declining the case was that it involved a "minor" offense. Id. at 269. Frase noted, as a general matter: "Trivial cases are not declined for lack of manpower, but because a policy decision has been made that these cases do not require criminal prosecution, at least in federal court." Id. at 281. In 1993, U.S. Attorneys' Offices declined to prosecute $27.6 \%$ of the weapons defendants referred to them-a figure slightly lower than the $30.9 \%$ overall rate. Sourcebook, supra note 9 , at 465 tbl.5.16. Although declination statistics may merely reflect agency referral practices, these figures are at least consistent with a story of prosecutorial selectivity.

${ }^{157}$ Prosecution of Federal Gun Crimes, supra note 148, at 50 (testimony of Jo Ann Harris, Ass't Atty. Gen., Criminal Div., U.S. Dep't of Justice).

${ }^{158}$ See Eisenstein, supra note 60, at 202-05; Scheingold, supra note 85, at 160 (finding that prosecutors in local jurisdiction studied "believed in a kind of contextual accountability that afforded protection against losing touch with the basic values and changing priorities of the public that they served"); Frank H. Easterbrook, Criminal Procedure as a Market System, 12 J. Legal Stud. 289, 302 (1983) ("[A]n examination of the cases prosecutors do and do not file suggests that decisions appear to be reasoned, responsible, and consistent with public perceptions of the gravity of different offenses...."). 
we can gain from provisionally assuming that the system largely works in this regard may be at least as illuminating as those we get by presuming the opposite on the basis of the same sort of sketchy evidence. One partial answer in the $\$ 922(\mathrm{~g})(1)$ context is that the federal government recently made a concerted effort to change the selection of defendants from a low to a high visibility decision. In April 1991, with much fanfare, Attorney General Thornburgh announced "Project Triggerlock," which would use federal firearms statutes to "protect the public by putting the most dangerous offenders in prison for as long as the law allows." 159 In August 1992, in coordination with "Triggerlock," the Director of the Bureau of Alcohol, Tobacco and Firearms announced "Operation Achilles Heel," which targeted over 600 "of this nation's most violent criminals" for federal firearms charges..$^{160}$ In doing so, the Director highlighted the nature of the targets' prior felony convictions: "murder, rape, crimes against children, aggravated assault, robbery, and so on."161

Perhaps these programmatic initiatives were, at least in part, an effort by the Bush Administration to blunt criticism for its opposition to the Brady Bill. ${ }^{162}$ But, even if they were, they show

${ }^{159}$ Tracy Thompson, Gun Crimes Targeted by Prosecutors; National Effort Seen as Partly Political, Wash. Post, Apr. 11, 1991, at A14 (quoting Attorney General Richard Thornburgh). See also Christopher Kilbourne, Police Add Ammunition against Gunmen: Cooperation Among Federal, State, Local Cops, The Record (Bergen), Apr. 11, 1991, at A3; U.S. Attorney's Office, Southern District of New York Report for 1991, at 3 (1992) (noting how, as part of "Operation Triggerlock," the U.S. Attorney's Office developed a "close relationship" with the Bureau of Alcohol, Tobacco and Firearms and "worked closely" with the New York City Police and Housing Police "to address the gun epidemic through selective application of justifiably harsh federal penalties to repeat offenders carrying guns, illegal gun dealers, and those using guns in the course of drug crimes and crimes of violence").

A follow-up memorandum by the head of the Criminal Division of the Justice Department to United States attorneys suggested that they screen "all state and local arrests within [their] district of felons ... who were in possession of a firearm at the time of their arrest." Norman Abrams \& Sara Sun Beale, Federal Criminal Law and Its Enforcement 89-90 (1993).

${ }^{160}$ Press Conference of Stephen E. Higgins, Director, Bureau of Alcohol, Tobacco and Firearms (Aug. 22, 1991) (Federal News Service transcript).

161 Id.

${ }_{162}$ Thornburgh Orders Drive on Gun Violence, N.Y. Times, Mar. 27, 1991, at A20 (When "pressed by reporters," Justice Department official denies that "Triggerlock" "was an effort to blunt mounting support in Congress for legislation controlling the sale of handguns. One such measure would prohibit dealers from delivering firearms 
how the Executive Branch can make its adherence to popular prosecutorial priorities into a political asset. The Executive Branch's efforts in this regard have continued during the Clinton Administration. ${ }^{163}$ The benefits of such a pre-commitment to community priorities (even where juries are unaware of the congruence) may also helps explain the prevalence of "career offender" programs in local prosecutors' offices. ${ }^{164}$

There are hmits, however, to how many low visibility decisions can be transformed into high visibility decisions for political gain. And there are similar limits to the number and type of cases at the other extreme-tlose in which a defense lawyer courting sympathetic publicity for her client (and maybe coincidentally for herself) can make a prosecution into a political liability. ${ }^{165}$ Our retired lobsterman is probably safe after all (at least in Maine or Massacliusetts). But what about the less pathetic cases? Perliaps a prosecutor will target offenders posing the greatest danger to the community, for fear of political fallout if they committed more serious crimes in the future. ${ }^{166}$ The risk of sucli fallout, lowever, will turn on whether a causal link can be drawn between the prosecutor's discretionary decisionmak-

to purchasers for a week, pending a police background check. The Bush Administration opposes the bill.").

${ }^{163}$ The Department of Justice continues to separate out "Project Triggerlock" cases when reporting case filing statistics. See Sourcebook, supra note 9, at 450, tbl. 5.5.

${ }^{164}$ See supra note 137 and accompanying text; see also Victor Navasky \& Darrell Paster, Law Enforcement: The Federal Role 65 (1976) (recounting how in 1975, "the President and the Attorney General both took time off from their other duties to pose for pictures" with local prosecutors who had come to receive federal grant money in connection with the Federal Law Enforcement Assistance Administration's Career Criminal program).

${ }^{165}$ Miller, supra note 68 , at 343 ("One of the ways in which interested persons, whether they be private citizens, judges, or police officials, sometimes influence charging practices is to enlist the aid of the publicity media.").

${ }_{166}$ See Standen, supra note 70, at $1499 \mathrm{n} .98$ ("It is possible for the prosecutor to internalize societal interests in plea settlements if the prosecutor suffers the harms from leniency directly.").

The political costs of a case where a nexus is perceived between official leniency or inaction and a subsequent crime were dramatically demonstrated in New York City recently, when a domestic violence defendant, released on bail after being charged with a misdemeanor, killed his ex-girlfriend. See Mayor Presses Ouster of Abuse Case Judge, N.Y. Times, Feb. 17, 1996, at 29; Joseph P. Fried, Duckman Is Returning, but to Civil Court, N.Y. Times, Apr. 26, 1996, at B1; Jim Dwyer, Free to Kill as DA Dallied, Daily News (New York), May 21, 1996, at 4; Maureen Fan, DA Had Role in Judge's Deadly Error, Daily News (New York), May 26, 1997, at 18. 
ing and the offenders' presence in the community. And the risk that such a link will be drawn is generally low for federal prosecutors, since state or local authorities are traditionally held responsible for crime, particularly violent crime, within their territorial jurisdiction.

Speculation on the calculus that drives selection of $\S 922(\mathrm{~g})(1)$ defendants cannot be separated froin speculation on prosecutorial motivation inore generally. Even assuming that direct political pressures on prosecutorial offices are felt down in the trenches, they surely do not figure in most of the decisions that lime prosecutors make from day to day. In the absence of potential jury input or media headlines, what other forces might make these prosecutors good (or bad) agents of their cominunities in the deployment of resources? For all the efforts to inodel or regulate prosecutorial behavior, so much more mquiry needs to be done into professional ideologies, role conceptions, and economic self-interest (both short-term and long-term) ${ }^{167}$ before we can begin to answer this question satisfactorily. ${ }^{168}$ As a former federal prosecutor, ${ }^{169} \mathrm{I}$ am tempted to suggest that prosecutors

${ }^{167}$ See, e.g., Richard W. Painter, Game Theoretic and Contractarian Paradigms in the Uneasy Relationship between Regulators and Regulatory Lawyers, 65 Fordham L. Rev. 149, 168-70 (1996) (reputational interests of agency lawyers influence agency behavior).

${ }^{168}$ Without sustained inquiry in this regard, the value of Tracey Meares's provocative proposal to reform charging practices by offering prosecutors relatively small financial incentives cannot possibly be assessed. See Tracey L. Meares, Rewards for Good Behavior: Influencing Prosecutorial Discretion and Conduct with Financial Incentives, 64 Fordham L. Rev. 851 (1995). A great many prosecutors have already forgone immediate flnancial rewards, perhaps because they prefer to invest in litigation skills, professional reputation, or political capital, or because of the personal satisfaction they derive from the work. The extent to which their behavior can be altered through cash payments will turn on the strength of these diverse preferences and the consistency of such preferences with the goals that payors seek to promote. For example, a scheme using small payments to deter prosecutorial misconduct during trial, for example, see id. at $902-07$, may be of no avail if the most rabid prosecutors enjoy the greatest success in attracting business once they become defense lawyers. See Weaver, supra note 69 , at $40-41$ (while younger lawyers in Antitrust Division "prefer more money to less money," what they want most "is the experience and skills they think they will need to recommend them in their future careers"; most intend to leave "well before the time they would become eligible for the pay and responsibility" of Division's "most senior lawyers").

${ }^{169}$ Between 1987 and 1992, I was an Assistant United States Attorney in the Southern District of New York. 
just happen to be a superior breed of public servant. Yet I will resist and simply say that behavior models based on conviction (or sentence-year) maximization are unacceptably simplistic. ${ }^{170}$

As in any bureaucratic organization, office ideology surely is an important, but as yet underexplored, factor in prosecutorial behavior. ${ }^{171}$ The esprit of a group that celebrates its mission of "getting bad guys" may make the unsuccessful prosecution of a "worthy" target (however defined) preferable to the easy case against the relatively harmless defendant. Of course, what a prosecutor might describe as a commitment to doing the "right thing" has also been called a dangerous sanctimoniousness. But however this ideology is described (and descriptions will differ from office to office), the point here is that it surely will have important (and probably salutary) effects on case-selection decisions.

Neither should the inquiry stop at internal organizational factors. Prosecutors may not be a "breed" of public servant after all, at least not in the bigger offices in this country-the offices in cities offering the broadest range of discretionary enforcement decisions, and future job opportunities. They are just lawyers, participating, to varying extents, in an occupational culture that transcends their role in the criminal justice system. ${ }^{172}$ To

${ }^{170}$ All efforts to model behavior will inevitably be somewhat reductionist. See Robinson, supra note 69 , at 85 ("Attempts to model bureaucratic behavior along rationalistic lines do not necessarily deny that individuals have complex and multifaceted utility functions, but they hypothesize that, in the bureaucratic environment, individual preferences converge on a singular utility maximand."). My point is that the oft-used prosecutorial behavior model is unacceptably so.

171 See Anthony Downs, Inside Bureaucracy, 243-44 (1967) ("Each bureau develops its ideology gradually through the investment of time and effort by its top leaders. This ideology is used to build up external support and internal cohesion among people who agree with its mission and activities as expressed in its ideology.").

${ }^{172}$ See James Q. Wilson, Bureaucracy: What Government Agencies Do and Why They Do It 60 (1989) ("In a bureaucracy, professionals are those employees who receive some significant portion of their incentives from organized groups of fellow practitioners located outside the agency."); Downs, supra note 171, at 95-96 ("[S]ome analysts of bureaus consider professionals as a separate bureaucratic type because each is more strongly infiuenced by his occupation than his organization ...."); see also Eisenstein, supra note 60, at 161 (Prosecutors "who regard themselves as 'officers of the court' and adhere to a 'due process' model rely more on their own legal judgments and less on the attitudes of agents."); Grosman, supra note 93, at 68 (While some prosecutors identify with the police and associate defense lawyers with their clients, "[o]thers identify with the values of the defense lawyers and accord these values some prestige. This is reflected in the prosecutor's own self-conception, 
what extent do prosecutors adhere to the norms of this occupational culture? $?^{173}$ And to what degree do norms about who "deserves" to be prosecuted reflect community preferences on such matters? These are only a few of the questions that a proper inquiry into prosecutorial accountability needs to explore.

In the end, hike Richard Fenno's members of Congress, each prosecutor surely has her "own mix of priorities and intensities-a mix which may, of course, change over time."174 But it would be helpful to have a working model of prosecutorial behavior-a model that will bring together such diverse factors as ideological self-selection, the constraints of office and courtroom, as well as long and short-terın economic incentives. We are quite far from that.

\section{CONCLUSION}

How much do rules of evidence restricting the information that jurors receive about defendants, victims, and crimes matter in the criminal justice system? Certainly they will influence the verdicts in particular trials; that at least has been the assumption of the rulemakers. But trials happen so rarely. Do the rules have appreciable effects on all the other cases, the ones that never make it to trial? If they do, by affecting the case-selection decisions by prosecutors seeking to maximize convictions, such rules threaten to create a disjunction between prosecutors' priorities and those of the communities they serve. This point need not been taken as an argument against the rules, since any costs in prosecutorial accountability must be weighed against the gains in verdict fairness and accuracy. The prospect of these systemic costs must be recognized, however. And, to the extent

one of being clearly a part of the general legal community, and in his interaction with defense lawyers."); cf. Frase, supra note, 94, at 563-64 (comparing careerism of French prosecutors with revolving door practices in the United States).

173 As Suzanne Weaver has noted:

[T] he close connections that [Antitrust Division lawyers, at all levels] maintain with their colleagues in the private antitrust bar ... provide a publicity that to a large extent compensates for a lack of detailed attention by the general public and that [division lawyers] regard as a powerful constraint on their actions.

Weaver, supra note 69 , at 160-61.

${ }^{174}$ Richard F. Fenno, Jr., Congressmen in Committees 1 (1973). 
they occur, these will be the costs of the rule that Old Chief has proinulgated for felon-in-possession cases.

In short, if prosecutors' primary criteria for selecting cases is likelihood of conviction and/or length of sentence, Old Chief is a troubling decision, threatenimg a regime of prosecution by stereotype. If it does not trouble us-and I don't believe it should-Old Chief challenges us to pursue the mysteries of prosecutorial motivation. The need to inaximize convictions will inevitably influence how prosecutors behave, whether elected or appointed. It is not the only influence, however, and it may not even be the inost important one. 